Utah State University

DigitalCommons@USU

$5-1981$

\title{
Effect of Atmospheric Oxidation on Bioavailability of Meat Iron and Liver Weights in Rats
}

Kathleen M. Cardon

Utah State University

Follow this and additional works at: https://digitalcommons.usu.edu/etd

Part of the Food Science Commons, and the Nutrition Commons

\section{Recommended Citation}

Cardon, Kathleen M., "Effect of Atmospheric Oxidation on Bioavailability of Meat Iron and Liver Weights in Rats" (1981). All Graduate Theses and Dissertations. 5242.

https://digitalcommons.usu.edu/etd/5242

This Thesis is brought to you for free and open access by the Graduate Studies at DigitalCommons@USU. It has been accepted for inclusion in All Graduate Theses and Dissertations by an authorized administrator of DigitalCommons@USU. For more information, please contact digitalcommons@usu.edu.

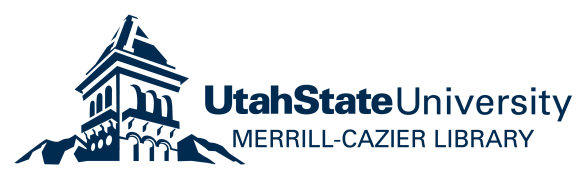


EFFECT OF ATMOSPHERIC OXIDATION ON BIOAVAILABILITY OF

MEAT IRON AND LIVER WEIGHTS IN RATS

by

Kathleen M. Cardon

A thesis submitted in partial fulfillment of the requirements for the degree

of

MASTER OF SCIENCE

in

Nutrition and Food Sciences

UTAH STATE UNIVERSITY

Logan, Utah 


\section{ACKNOWLEDGEMENTS}

This research project was made possible through financial support from the President's Overhead Fund. I am grateful for this financial assistance.

My sincere appreciation is extended to my major professor, Dr. Arthur Mahoney. His encouragement, assistance, patience, academic guidance and friendship have been invaluable during this scholarly endeavor.

In addition, Dr. Deloy Hendricks, Dr. Von Mendenha11, Dr. Rodney Brown and Dr. Daren Cornforth receive my thanks for their responses to inquiries and for their advice. My fellow graduate students are offered thanks for intellectual comradery and assistance in research.

To my husband, Bart, I offer my love and gratitude. He has supported and sustained me through trials and success during my career as a graduate student as well as through 1ife. To my children, Joe, Steve, David, Peter and John, I give my love and appreciation for their support. To my parents who initially guided me in the wonder of learning, I convey my love. 
ACKNOWLEDGEMENTS ........................

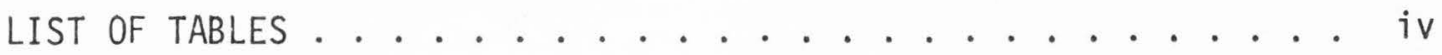

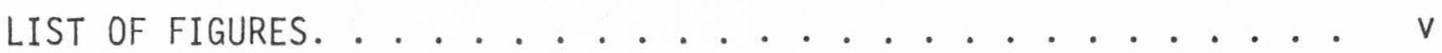

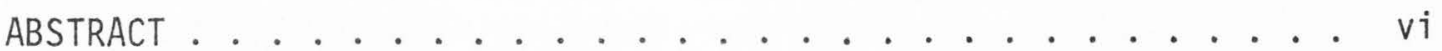

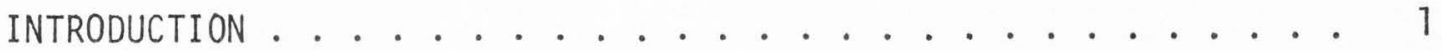

Factors Affecting Absorption and Metabolism of Iron. . . . . 1

Effects of Oxidized Lipids on Growth. ........... 3

Mechanism of Oxidation of Lipids. . . . . . . . . 5

Oxidation of Lipids and Bioavailability of Iron . . . . . . 6

Rationale ................... 7

EXPERIMENT I. EFFECT OF ATMOSPHERIC OXIDATION ON IRON BIOAVAILABILITY OF HAND-DEBONED TURKEY MEAT. . . . . . . . . . . . 9

Experimental Procedure............... 9

Results..................... 15

Discussion. . . . . . . . . . . . . . 17

EXPERIMENT II. EFFECT OF ATMOSPHERIC OXIDATION AND FORMALDEHYDE ON IRON BIOAVAILABILITY OF MECHANICALLY DEBONED BEEF . . . . . . 19

Experimental Procedure. . . . . . . . . . . 19

Results................... . . 22

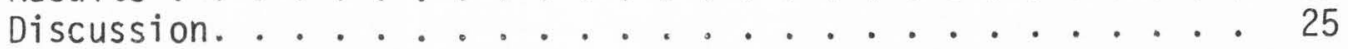

EXPERIMENT III. A COMPARISON OF THE EFFECT OF ATMOSPHERIC OXIDATION ON HAND DEBONED AND MECHANICALLY DEBONED LYOPHILIZED TURKEY MEAT AND HAND DEBONED AND MECHANICALLY DEBONED LYOPHILIZED BEEF MEAT

Experimental Procedure. . . . . . . . . . . 31

Results................. . . . 33

Discussion. . . . . . . . . . . . . . 40

FINAL STATEMENT. . . . . . . . . . . . . . . . 48

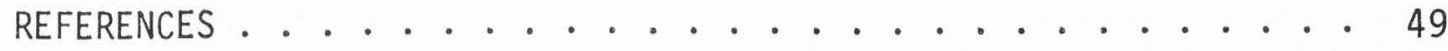

APPENDICES ........................ 53

Appendix A. Micro Kjeldahl Method. . . . . . . . . . 54

Appendix B. Soxhlet Method ............. 56 56

Appendix C. 2-Thiobarbituric Acid Method ........ 57

Appendix D. Iodine Number. . . . . . . . . . 58 


\section{LIST OF TABLES}

Table

1. Vitamin mixture used in diets for iron bioavailability experiments ................ 10

2. Mineral mixture added to diets used in determining iron bioavailability of oxidized turkey meat . . . . . . . . 13

3. Growth response of anemic rats fed diets containing lyophilized oxidized hand deboned turkey meat for 10 days . . 17

4. Hematinic responses of anemic rats fed diets containing lyophilized oxidized hand deboned turkey meat for

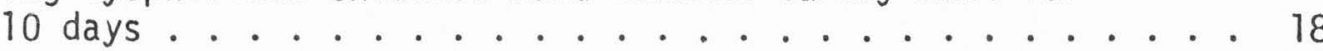

5. Mineral mixture added to diets used in determining iron bioavailability of mechanically deboned oxidized beef.................... 20

6. Composition of diets in Experiment 2........... . 21

7. Growth response of anemic male rats fed lyophilized mechanically deboned beef diets or diets containing formaldehyde.

8. Hematinic responses of anemic male rats fed lyophilized mechanically deboned beef diets or diets containing formaldehyde.

9. Summary of hematinic responses of anemic male rats fed lyophilized mechanically deboned beef diets or diets containing formaldehyde ...............

10. Analytical composition of uncooked, ground, lyophilized meat before oxidation . . . . . . . . . . . . . 34

11. TBA values ( $\mu \mathrm{g}$ malonaldehyde/g) of meat samples before and after oxidation............ . . . 34

12. Iodine number (calculated as $\mathrm{g} \mathrm{I}_{2}$ absorbed per $100 \mathrm{~g}$ sample) of meat samples before and after oxidation......

13. Iodine number (calculated as $\mathrm{g}$ I2 absorbed per $100 \mathrm{~g}$ fat in sample) of meat samples before and after oxidation 
Figure

1. Relationship of TBA value (expressed as malonaldehyde, ma1.) and formaldehyde value to number of hours lyophilized turkey meat was exposed to air............ 16

2. TBA value ( $\mu \mathrm{g}$ malonaldehyde/g) of meat samples at 0 hours and 336 hours oxidation. ........... 35

3. Iodine number (calculated as $\mathrm{g} \mathrm{I}_{2}$ absorbed per $100 \mathrm{~g}$ sample) of meat samples before and after oxidation . . . . . . 38

4. Iodine number (calculated as $\mathrm{g} \mathrm{I}_{2}$ absorbed per $100 \mathrm{~g}$ fat in sample) of meat samples before and after oxidation. . 39 


\section{ABSTRACT}

Effect of Atmospheric Oxidation on Bioavailability of Meat Iron and Liver Weights in Rats

by

Kathleen M. Cardon, Master of Science Utah State University, 1981

Major Professor: Arthur W. Mahoney

Department: Nutrition and Food Sciences

Iron bioavailability of diets containing oxidized turkey and oxidized beef meat was investigated in two experiments. In both studies male, weanling rats were made anemic by consumption of a low iron diet and bleeding. The experimental diets were prepared so that meat was the only source of iron. Hemoglobin regeneration served as the basis for measuring iron utilization. In experiment 1, lyophilized, uncooked turkey meat was allowed to oxidize at $20-22^{\circ} \mathrm{C}$ for $0,48,96,144,216$, or 264 hours and then fed to the rats. The length of oxidation time of the turkey meat did not significantly affect the growth of the rats or the bioavailability of the meat iron. In experiment 2, 1yophilized, uncooked beef was allowed to oxidize at $20-22^{\circ} \mathrm{C}$ for 14 days. Anemic rats were fed diets composed of basal, basal + iron, basal + iron + formaldehyde, 100\% fresh beef, $75 \%$ fresh $25 \%$ oxidized beef, $50 \%$ fresh-50\% oxidized beef, $25 \%$ fresh- $75 \%$ oxidized, $100 \%$ oxidized beef and 100\% fresh beef + formaldehyde. Rats fed severely oxidized beef diets had decreased body weight, enlarged livers and depressed hematinic responses. Formaldehyde did not significantly affect iron utilization in rats fed basal diets, but 
depressed 1 iver iron storage in rats fed fresh beef. A third experiment to further compare the chemical properties of uncooked, lyophilized hand deboned and mechanically deboned beef and turkey meat was performed. Analysis by the Thiobarbituric Acid Method, Formaldehyde Value, and Iodine Number indicated increased sophistication of testing methods for lyophilized meats needs to be developed. Although the Thiobarbituric Acid Method was successfully used in Experiment 1, unreliable results were obtained using this method in Experiment 3. It is assumed that this variability in results is due to using the Thiobarbituric Acid Method with a dry system. The problems encountered with the Formaldehyde Value included contamination of the water supply with aldehydes and unreliable reagent. The Iodine Number was unreliable used on meat samples. Possibly the fat could be extracted from the meat under cool nitrogen to prevent further oxidation of the fat. Then the iodine number could be determined on the extracted fat. 
INTRODUCTION

Factors Affecting Absorption and Metabolism of Iron

The total amount of iron in the diet does not reflect the amount of iron actually absorbed and utilized. The main control of iron absorption is at the site of the intestinal mucosa (Pike and Brown, 1975). "When the dietary supply of absorbable iron is sufficient, the intestinal mucosa regulates iron absorption in a manner that tends to keep the body iron content consistent" (National Research Council, 1980, p. 138). However, the mechanisms for regulating iron homeostasis are not known. Erythropoietic rate, iron stores, anemia, and intraluminal chelating and complexing agents influence iron absorption, probably via their effects on the intestinal mucosal cells (VanCampen, 1974).

Furthermore, various iron salts have different relative biological values. Mahoney and Hendricks (1976) found that ferric orthophosphate was $51 \%$ as efficient as ferrous sulfate for hemoglobin regeneration in the anemic rat. Also, ferric chioride, ferric orthophosphate, reduced iron, and sodium iron pyrophosphate are ranked in order from most efficient to least efficient in effectiveness of iron retention and hemoglobin regeneration in the anemic rat (Wade11, 1974). Likewise, the iron in various foods differs in its bioavailability. It has been found that the percent efficiency of converting iron in the following diets to hemoglobin is $\mathrm{FeSO}_{4}$, 51; egg diet, 45; beef diet, 43; whole wheat flour diet, 33; and enriched flour diet, 24 (Mahoney et al. 1974).

Besides, there are numerous dietary influences upon iron absorption. Hegsted et a1. (1949) concluded that the absolute amount of iron and/or phosphorus in the diet as well as the iron-phosphorus ratio influences 
the amount or iron absorbed. They concluded that a low level of phosphorus in the diet led to excessive iron stores in the liver. Conversely, addition of phosphorus salts decreased the iron deposited in the liver. In addition, the inclusion of phytate in the diet decreases iron absorption. Bjorn-Rasmussen (1974) concluded that the addition of $7 \%$ bran to wheat bread decreased iron absorption by a factor of two. The marked reduction in iron absorption was ascribed to the content of phytate in bran. Layrisse et al. (1968) concluded that the interaction of vegetable with animal food during digestion may change the pattern of iron absorption if these foods were given alone. Further, he suggests that a certain proportion of animal food should be included in the diet to enhance iron absorption from the vegetable food. Cook and Monson (1976) determined that neither protein nor animal protein per se enhances iron absorption. They found that the inclusion of beef, lamb, pork, chicken, liver and fish in the diet increases the rate of non-heme iron absorption. In contrast, milk, cheese and eggs do not increase iron absorption and may decrease iron availability. In addition, the addition of vitamin $C$ to the diet may increase the absorption of non-heme iron by a four fold factor (BjornRasmussen and Hallberg, 1974; Cook and Monson, 1977). Increased iron absorption and iron deposition in the liver was found when rats were fed a low-protein, high fat diet (Kaufman et al., 1958). Amine and Hegsted (1975) found that diets high in fat favored iron utilization. In fact, iron absorption was greater in diets in which the fat was supplied as coconut oil rather than corn oil. Hemoglobin concentration was used as the criteria for iron utilization. Conversely, Farmer (1977) found that high fat diets decrease iron absorption when iron 
bioavailability data is interpreted on the basis of hemoglobin regeneration. When the data is interpreted on the basis of percent efficiency in converting dietary iron into hemoglobin, the effect of lipid source and level on iron utilization was found to be negligible.

Hence, the amount of metabolizable iron is dependent upon the organism's present supply of iron, the amount of iron present in the diet, the efficiency of utilization of the iron source, and numerous dietary factors.

\section{Effects of Oxidized Lipids on Growth}

The consumption of oxidized fats by animals has been reported to have various physiological effects (Kaunitz et al., 1965; Kaunitz et al., 1966). Consumption of oxidized fats by rats has affected longevity. Andrews et a1. (1956) showed that rats consuming a severely oxidized soybean $0 i 1$ diet (1200 peroxide number) died within approximately three weeks. Kaunitz et a1. (1955) demonstrated that rats fed mildly oxidized cottonseed oil, chicken fat and beef fat in a long term nutritional study showed a higher death rate than those fed the corresponding fresh fats. Kaunitz et a1. (1956) continued their studies and discovered that feeding mildly heated and aerated butter and lard did not significantly reduce the life span of rats. With similarly treated soybean and corn oils, survival was as good as with fresh animal fat. In contrast, feeding fresh vegetable oils led to significantly shorter life spans.

In addition, oxidized fat in the diet has been reported to reduce the rate of growth. Nolen et a1. (1967) fed rats diets consisting of $15 \%$ fat which had been used for frying until it was unfit for further use. In a two year study the rats fed the oxidized fat had slower 
growth rates than rats fed fresh fat diets. However, there were no clinical, metabolic or pathological criteria to suggest that the oxidized fats adversely affected the rats consuming them. Nolen (1973) also reported decreased growth in dogs when hydrogenated soybean oil was used for deep fat frying under commercial conditions until it became unfit for further use. Nakamura et a1. (1973) found that autoxidized safflower oil administered daily by intubation to rats caused reduced growth.

Enlarged livers are commonly reported in animals fed oxidized fat. Kaunitz et a1. (1955) found enlarged livers in rats fed refined cottonseed oil which had been aerated and heated to $95^{\circ} \mathrm{C}$ for $200-300$ hours. A diet containing $10 \%$ rancid soybean 011 (peroxide number 530 550) supported almost normal growth in rats, although they did have enlarged livers reported Greenberg and Frazer (1953). Likewise, Miller and Landes (1975)reported enlarged livers in rats fed oxidized or heated soybean 0i1. In addition, Andia and Street (1975) have reported enlarged livers in rats fed thermally oxidized fat.

When autoxidized safflower oils were fed to rats, Nakamura et al. (1973) found no significant changes in the liver, but found marked changes in the endoplasmic retriculum. Also, activity of the enzymes serum glutamic pyruvic transminase and serum glutamic oxaloacetic transaminase were increased. Furthermore, Andia and Street (1975) reported that rats fed thermally oxidized fats had increased smooth endoplasmic reticulum proliferation plus an induction of complex microsomal enzymes in the livers. 


\section{Mechanism of Oxidation of Lipids}

Fats may become rancid as a result of lipolysis, a reaction wherein the ester linkages of lipids are subject to hydrolysis resulting from enzymes, from thermal stress, or from chemical action. Fats may also become rancid as a result of oxidation. 0xidation usually proceeds through a free radical chain reaction mechanism which involves (1) initiation, formation of the free radical, (2) propagation, free radical chain reaction and (3) termination, formation of nonradical products. The major initial products of reactions between fatty acids and oxygen are peroxides. Initially an unsaturated hydrocarbon looses a hydrogen to form a radical, $R H \rightarrow R \cdot+H \cdot$. Then oxygen adds at the double bond to form a diradical. During propagation, the chain reaction continues as follows:

$$
\begin{aligned}
& R \cdot+\mathrm{O}_{2} \rightarrow \mathrm{ROO} \cdot \\
& R 00 \cdot+\mathrm{RH} \rightarrow \mathrm{ROOH}+\mathrm{R} .
\end{aligned}
$$

The result is the formation of peroxy radicals, hydroperoxides, and new hydrocarbon radicals. Termination occurs when two radicals interact.

$$
\begin{aligned}
& \mathrm{R} \cdot+\mathrm{R} \cdot \rightarrow \mathrm{RR} \\
& \mathrm{ROO} \cdot+\mathrm{R} 00 \cdot \rightarrow \mathrm{ROOR}+\mathrm{O}_{2} \\
& \mathrm{RO} \cdot+\mathrm{R} \cdot \rightarrow \mathrm{ROR} \\
& \mathrm{ROO} \cdot+\mathrm{R} \cdot \rightarrow \mathrm{ROOR} \\
& 2 \mathrm{RO} \cdot+2 \mathrm{ROO} \cdot 2 \mathrm{ROOR}+\mathrm{O}_{2}
\end{aligned}
$$

Hydroperoxides are easily decomposed by a number of factors including high energy radiation, thermal energy, metal catalysis, and enzyme activity. Iron may act as a metal prooxidant in hydroperoxide decomposition which results in the formation of additional radicals. The 
reaction which takes place is:

$$
\begin{aligned}
& \mathrm{Fe}^{++}+\mathrm{ROOH} \rightarrow \mathrm{RO} \cdot+\mathrm{OH}^{-}+\mathrm{Fe}^{+++} \text {The reduced metal is oxidized. } \\
& \frac{\mathrm{Fe}^{+++}+\mathrm{ROOH} \rightarrow \mathrm{ROO} \cdot+\mathrm{H}^{+}+\mathrm{Fe}^{++}}{2 \mathrm{ROOH} \rightarrow \mathrm{RO} \cdot+\mathrm{ROO}+\mathrm{H}_{2} \mathrm{O}} \text { The oxidized metal is reduced. }
\end{aligned}
$$

Hydroperoxides decompose easily in the presence of multivalent metal ions such as iron to form both $\mathrm{RO}$ - and $\mathrm{ROO}$. radicals as the metal ions undergo oxidation-reduction.

Heme compounds have been attributed to being oxidation catalysts. The heme compounds may initiate peroxidation or may function as peroxide decomposers. However, when heme compounds are present at two to four times the amount needed for the most effective oxidation, the heme compounds exert an antioxidant effect and no oxidation takes place (Fennema, 1976).

Another aspect of lipid oxidation and metal catalysts which is of importance is water activity. Water activity can influence the rate of reaction in a lipid phase. With a decrease in water activity, the rate of oxidation first decreases. However, with a further decrease of water activity, the rate of oxidation increases. This particular effect is attributed to several factors, among them changes in hydration of trace metal catalysts which become more active as they lose water (Labuza, 1980).

\section{Oxidation of Lipids and Bioavailability of Iron}

A great deal of research has been done on factors affecting absorption and metabolism of iron. Also, several research papers have been published on the growth retardation effects of including oxidized 
lipids in the diet. However, very little information exists on the effects of oxidation on iron bioavailability. "Cotton-fur" syndrome in mink fed diets of Pacific hake (Merluccius productus) is due to an induced iron deficiency anemia that is responsive to intramuscular iron supplementation (Stout et a1., 1960a). The iron deficiency could be prevented by cooking the hake thoroughly (Stout et al., 1960b). The flesh of hake may contain 15-300 ppm of formaldehyde depending on the tissue assayed and the duration of the storage (Mendenhal1, 1970; Amano and Yamada, 1964). It has been shown that formaldehyde accumulates in some meats as oxidation takes place (Andrews et al., 1977). Miller and Landes (1975) reported that rats fed diets high in oxidized or damaged oil absorbed and utilized iron for hemoglobin synthesis less efficiently than rats fed diets containing fresh oil.

\section{Rationale}

Iron deficiency anemia is recognized as a major nutritional disorder particularly among infants, children and women during the female reproductive period and during pregnancy (AMA, 1968; National Research Counci1, 1980). As the prevalence of this disorder is so wide spread among several populations, it is important to ascertain any factors which may lead to this disorder. A few studies have implicated oxidized fats (Stout et a1., 1960a; Stout et al., 1960b; Miller and Landes, 1975) as causing anemia or decreased hemoglobin synthesis. Hence, it was decided to further investigate this possibility.

Freeze drying or lyophilizing food allows a system wherein reaction rates are low and structural changes are minor. Due to the decreased moisture the food could be exposed to air for the oxidation period without 
contamination from bacterial growth. Further, in using meat as the product tested, both factors to be tested were present; that is, iron and fat. 


\author{
EXPERIMENT I \\ EFFECT OF ATMOSPHERIC OXIDATION ON IRON BIOAVAILABILITY \\ OF HAND-DEBONED TURKEY MEAT
}

\title{
Experimental Procedure
}

\section{Meat Preparation}

Meat was gleaned from turkey frames by hand, ground, and 1yophylized. The lyophylized, uncooked, turkey meat was spread evenly to a depth of approximately $5 \mathrm{~mm}$ on plastic trays and allowed to oxidize at $20-22^{\circ} \mathrm{C}$ for $0,48,96,144,216$ or 264 hours. After portions of turkey meat were exposed to air for the specified number of hours, they were vacuum packed and stored at $-40^{\circ} \mathrm{C}$ until the experimental diets were prepared.

\section{Preparation of Diets}

A low-iron diet and six experimental diets were prepared using stainless steel equipment which was cleaned and rinsed with deionized water before each diet was prepared. The diet ingredients were mixed in an electric mixer with an epoxy coated bowl and paddle.

The low-iron diet prepared to aid in developing iron deficiency contained (in g/kg diet): casein, $327 \mathrm{~g}$; dextrose, $418 \mathrm{~g}$; rendered turkey fat, $170 \mathrm{~g}$; $\alpha$-ce11ulose, 25g; vitamin mixture, $20 \mathrm{~g}$ (Table 1); and mineral mixture, $40 \mathrm{~g}$ (Table 2). The quantity of casein used was based upon the assumption that casein contains $85 \%$ protein. A11 ingredients were weighed to the nearest gram.

Six experimental diets were prepared, each differing from the others only in terms of the number of hours the meat was exposed to the air. The diets were formulated to contain $27.9 \%$ protein, $18.1 \%$ 
Table 1. Vitamin mixture ${ }^{1}$ used in diets for iron bioavailability experiments

$$
\text { Vitamin } \quad \mathrm{g} / \mathrm{kg} \text { mixture }{ }^{2} \quad \mathrm{mg} / \mathrm{kg} \text { diet }
$$

Vitamin A concentrate

$(200,000$ IU retinyl acetate/g) $\quad 4.5 \quad 90$

Vitamin $D$ concentrate

$\begin{array}{lll}(400,000 \mathrm{IU} \text { calciferol/g) } & 0.25\end{array}$

Alpha-tocopherol

$5.0 \quad 100$

Ascorbic acid

45.0

900

Inositol

5.0

100

Choline Chloride

75.0

1500

Menadione

2.25

45

p-Aminobenzoic acid

5.0

100

Niacin

4.5

90

Riboflavin

1.0

20

Pyridoxine hydrochloride

1.0

20

Thiamine hydrochloride

1.0

20

Calcium pantothenate

3.0

60

Biotin

0.020

0.4

Folic acid

0.090

1.8

vitamin $B_{12}$

0.00135

0.27

${ }^{1}$ Vitamin Diet Fortification Mixture supplied by Nutritional Biochemicals Corporation, Cleveland, Ohio.

${ }^{2}$ These amounts were made up to $1 \mathrm{~kg}$ with dextrose. 
fat and $20.1 \mathrm{ppm}$ iron. The meat was the sole source of iron. These diets contained (in $\mathrm{g} / \mathrm{kg}$ ) lyophylized turkey meat, $473 \mathrm{~g}$; dextrose, $442 \mathrm{~g}$; $\alpha$-cellulose, $25 \mathrm{~g}$; vitamin mixture, $20 \mathrm{~g}$; and mineral mixture, $40 \mathrm{~g}$. The vitamin and mineral mixtures were identical to those used in the low-iron diet. All diets were stored at refrigeration temperatures.

Animals and Animal Care

Sixty weanling, male Sprague Dawley rats (obtained from Simonsen Laboratories, Gilroy, California) were housed individually in stainless steel cages in a temperature controlled room. The rats were fed ad libitum the low-iron casein diet (11.6 ppm Fe) for 14 days. About 0.7 cc blood was taken by capillary tube from the retro-ocular capillary bed on the third and eighth days to increase the anemic condition.

On the fourteenth day the rats were weighed and hemoglobin measurements taken. The rats were then assigned to six groups of ten each so that mean hemoglobin concentration and mean body weights were similar; 4.60-4.76 g/dl and 68-74 g, respectively. Eight to ten grams of the experimental diets were fed daily to each rat for 10 days according to the following schedule: $8 \mathrm{~g}$ on day $1,10 \mathrm{~g}$ on days $2-3,9 \mathrm{~g}$ on days 4-7, and $8 \mathrm{~g}$ on days 8-10. The feed schedule was adjusted to minimize the amount of unconsumed diet. The diet allowance was weighed out daily and any remaining diet in food cups weighed and subtracted from the daily intake. Demineralized water was allowed ad libitum during the entire experiment.

At the conclusion of the 10-day experimental feeding period, body weights and hemoglobin values were again measured. The rats were killed by decapitation and the livers and spleens weighed. The livers were 
Table 2. Mineral mixture added to diets used in determining iron bioavailability of oxidized turkey meat

\begin{tabular}{lccc}
\hline \multicolumn{1}{c}{ Salt } & $\mathrm{g} \mathrm{salt} / \mathrm{kg}$ mixture & Mineral & $\mathrm{mg}$ mineral/kg diet \\
\hline $\mathrm{CaHPO}_{4} \cdot 2 \mathrm{H}_{2} \mathrm{O}$ & 610.75 & $\mathrm{Ca}$ & 5,690 \\
$\mathrm{KCl}$ & 105.15 & $\mathrm{P}$ & 4,397 \\
$\mathrm{NaCl}$ & 38.125 & $\mathrm{Na}$ & 2,206 \\
$\mathrm{MgCO}_{3}$ & 34.675 & $\mathrm{Mg}$ & 600 \\
$\mathrm{MnSO}_{4} \cdot \mathrm{H}_{2} \mathrm{O}$ & 4.275 & $\mathrm{Mn}$ & 400 \\
$\mathrm{ZnSO}_{4} \cdot 7 \mathrm{H}_{2} \mathrm{O}$ & 1.25 & $\mathrm{Zn}$ & 55.6 \\
$\mathrm{CuSO}_{4} \cdot 5 \mathrm{H}_{2} \mathrm{O}$ & 0.55 & $\mathrm{Cu}$ & 11.4 \\
$\mathrm{KI}^{2}$ & 0.0055 & $\mathrm{I}$ & 5.6 \\
$\mathrm{Na}_{2} \mathrm{SeO}_{3}$ & 0.0023 & $\mathrm{Se}$ & 0.17 \\
\hline
\end{tabular}

individually packaged in cellophane, labeled and frozen for later iron analysis.

\section{Analytical}

The micro-Kjeldahl method was used for determining the nitrogen content of the meat (Appendix A). Crude protein was then determined by assuming that protein contains $16 \%$ nitrogen. Hence, the percent nitrogen is multiplied by a factor of 6.25 to determine the crude protein. The lipid content was analyzed using the Soxhlet method (Appendix B). Meats, diets, and livers were charred in porcelain crucibles and then ashed at $500-600^{\circ} \mathrm{C}$ for 24 hours. The ash residue of each was solubilized with $10 \mathrm{ml} 6 \mathrm{~N} \mathrm{HCl}$, heated to boiling, transferred to acid washed plastic bottles, and diluted to $25 \mathrm{ml}$ with demineralized water. These samples were analyzed for iron content by atomic absorption spectrophotometry 
at 2483 A using an air-acetylene flame. Triplicate samples were used in a 11 the above determinations with the exception of the livers. The oxidized turkey meat was analyzed for malonaldehyde using the 2-Thiobarbituric Acid Method (Sinnhuber and Yu, 1958) (see Appendix C). In addition, the oxidized turkey meat was analyzed for formaldehyde (Andrews et a1., 1977) (see Appendix D). The above chemical analysis were done in duplicate.

Hemoglobin $(\mathrm{Hb})$ concentrations were measured in duplicate samples of fresh blood using the cyanmethemoglobin method of crosby et al. (1954). Hemoglobin regeneration was calculated in four ways: (1) hemoglobin gain $(g / d l)$ is computed as the difference between final and initial hemoglobin concentrations; (2) hemoglobin gain (g) is the difference between final and initial hemoglobin levels. Final and initial hemoglobin levels are calculated assuming that $6.7 \%$ of the body weight reflects blood volume. Hence, hemoglobin $(\mathrm{g})$ is calculated by multiplying $6.7 \%$, the body weight and the hemoglobin concentration; (3) hemoglobin iron gain (mg) is calculated based on the assumption that the iron concentration of hemoglobin is $3.35 \mathrm{mg} / \mathrm{g}$. The hemoglobin iron gain $(\mathrm{mg})$ is therefore the product of hemoglobin gain $(\mathrm{g})$ and 3.35 per cent iron; (4) hemoglobin iron gain per unit iron intake $(\mathrm{mg} / \mathrm{mg}$ ) is the hemoglobin iron gain $(\mathrm{mg})$ divided by the food iron consumption (mg) (Mahoney et a1., 1974).

\section{Statistical Analysis}

The data were analyzed by analysis of variance. When treatment " $F$ " was statistically significant $(P<.05)$, least significant difference (LSD) values were calculated (Carmer and Swanson, 1973). 


\section{Results}

\section{Meat Composition}

The 1yophilized meat (less than $5 \%$ moisture) contained $53 \mathrm{mg} \mathrm{Fe}$, $383 \mathrm{~g}$ fat and $589 \mathrm{~g}$ protein per $\mathrm{kg}$.

The turkey meat diets contained approximately 30 ppm Fe (Tables 3 and 4 ). (Every attempt was made to prevent iron contamination during the preparation of the diets. However, the analyzed values, approximate1y $30 \mathrm{ppm} \mathrm{Fe}$, exceeded the formulated value, $20.1 \mathrm{ppm} \mathrm{Fe.)}$

The thiobarbituric acid (TBA) and formaldehyde values for the turkey meat are plotted in Figure 1. The relationship between oxidation time in hours $(X)$ and TBA value $(Y)$ was $Y=0.0729 X+10.27 ; r=0.97$. The relationship between oxidation time $(X)$ and formaldehyde value $(Y)$ was $Y=0.0690 X+1.6428 ; r=0.9997$.

\section{Animal Responses}

The growth responses of the anemic rats fed the lyophilized turkey meat which had been allowed to be oxidized for varying lengths of time are reported in Table 3. Body weight gains and liver weights did not differ significantly among groups. Although significant $(P<0.05)$ differences among treatments were found for spleen weights and liver as a percent of body weight, the differences were random in relationship to the dietary variables.

The hematinic responses of the rats are shown in Table 4 . There were no significant $(P<0.05)$ differences among groups except in liver iron $(\mu g)$. Again the differences were random in relationship to the dietary variables. 


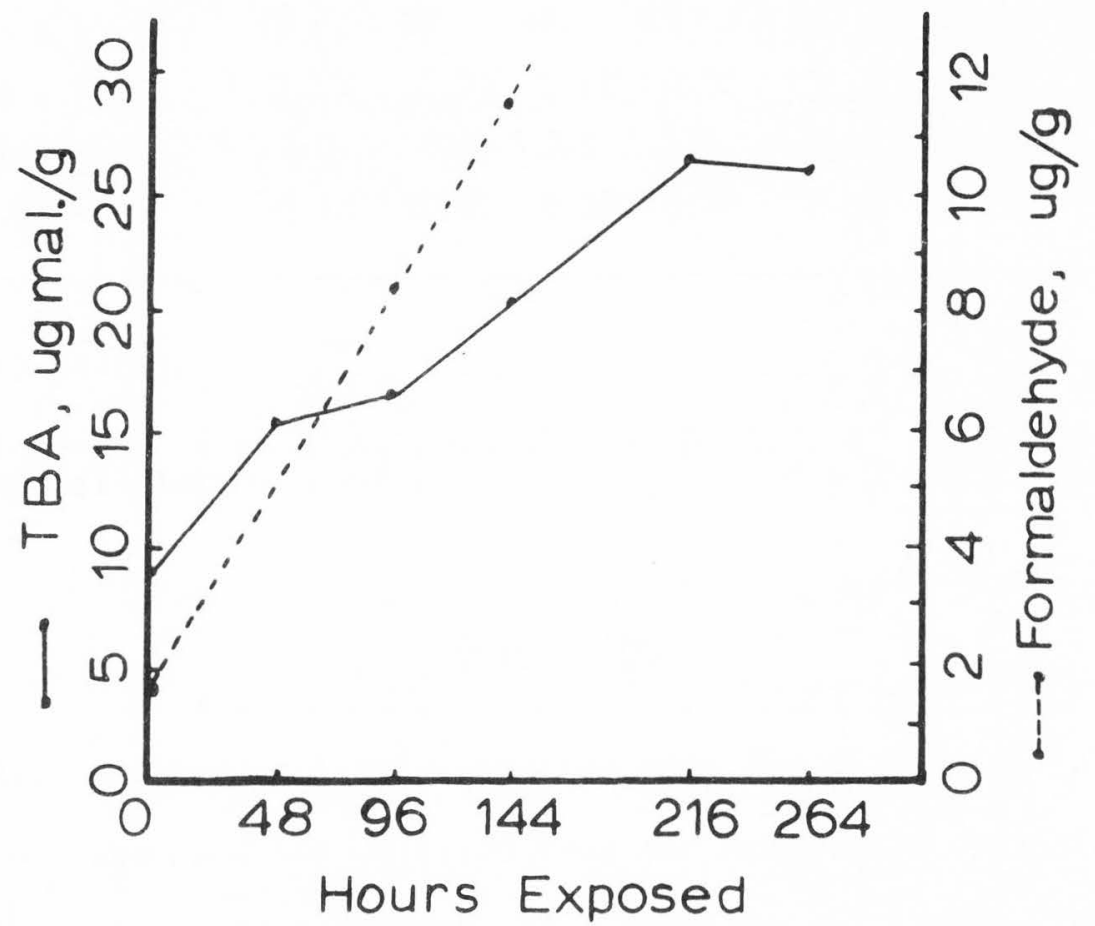

Figure 1. Relationship of TBA value (expressed as malonaldehyde, mal.) and formaldehyde value to number of hours lyophilized turkey meat was exposed to air 
Table 3. Growth response of anemic rats fed diets containing lyophilized oxidized hand deboned turkey meat for 10 days

\begin{tabular}{lcccccccc}
\hline & \multicolumn{7}{c}{ Oxidation Time (Hours) } & LSD \\
& 0 & 48 & 96 & 144 & 216 & 264 & $05 / 01$ \\
\hline Dietary Fe, $\mu \mathrm{g} / \mathrm{g}$ & 30.4 & 30.7 & 30.3 & 29.8 & 29.2 & 31.2 & - \\
No. of rats & 10 & 10 & 10 & 10 & $9^{2}$ & 10 & - \\
BW initial, g & 70 & 68 & 70 & 70 & 74 & 68 & NS \\
BW gain, g & 29 & 30 & 27 & 29 & 26 & 27 & NS \\
Liver, g & 2.99 & 2.94 & 2.80 & 2.95 & 3.03 & 3.02 & NS \\
Liver, \% of BW & 3.0 & 3.0 & 2.9 & 3.1 & 3.0 & 3.2 & $0.2 / 0.3$ \\
Spleen, g & 0.40 & 0.41 & 0.38 & 0.45 & 0.30 & 0.36 & $.08 / .11$ \\
\hline
\end{tabular}

'Analyzed values.

${ }^{2}$ One rat in this diet group died within 24 hours of receiving the experimental diet.

\section{Discussion}

Miller and Landes (1975) reported rats fed diets high in oxidized soybean oil absorbed and utilized iron for hemoglobin synthesis less efficiently than rats fed fresh oil. Stout et a1. (1960a, 1960b) have associated iron deficiency with formaldehyde in feed in mink. It has been shown that formaldehyde accumulates in some meats as oxidation takes place (Andrews et a1., 1977). However the results of this experiment do not confirm a relationship between iron deficiency and oxidized turkey meat. The varying degrees of oxidation of the lyophilized, uncooked turkey meat did not affect either animal growth or bioavailability of meat iron for the rats in this experiment. 
Table 4. Hematinic responses of anemic rats fed diets containing lyophilized oxidized hand deboned turkey meat for 10 days

\begin{tabular}{|c|c|c|c|c|c|c|c|}
\hline & \multirow[b]{2}{*}{0} & \multicolumn{5}{|c|}{ Oxidation Time (Hours) } & \multirow{2}{*}{$\begin{array}{l}\text { LSD } \\
05 / 01\end{array}$} \\
\hline & & 48 & 96 & 144 & 216 & 264 & \\
\hline Dietary $\mathrm{Fe}, \mu \mathrm{g} / \mathrm{g}^{1}$ & 30.4 & 30.7 & 30.3 & 29.8 & 29.2 & 31.2 & -- \\
\hline No. of rats & 10 & 10 & 10 & 10 & $9^{2}$ & 10 & -- \\
\hline Fe intake, mg & 2.61 & 2.64 & 2.64 & 2.64 & 2.65 & 2.64 & NS \\
\hline $\mathrm{Hb}$ initial, g/dl & 4.65 & 4.64 & 4.63 & 4.67 & 4.76 & 4.60 & NS \\
\hline Hb gain, g/dl & 3.77 & 3.73 & 3.69 & 3.68 & 4.23 & 3.74 & NS \\
\hline $\mathrm{Hb}-\mathrm{Fe}$ gain, mg & 1.13 & 1.12 & 1.08 & 1.13 & 1.22 & 1.08 & NS \\
\hline $\begin{array}{c}\mathrm{Hb}-\mathrm{Fe} / \mathrm{Fe} \text { intake, } \\
\mathrm{mg} / \mathrm{mg} \times 100\end{array}$ & 43 & 42 & 41 & 43 & 46 & 41 & NS \\
\hline Liver $\mathrm{Fe}, \mu \mathrm{g} / \mathrm{g}$ & 33.8 & 34.9 & 33.9 & 37.3 & 39.4 & 37.0 & NS \\
\hline Liver $\mathrm{Fe}, \mu \mathrm{g}$ & 103 & 102 & 95 & 112 & 119 & 112 & $12 / 16$ \\
\hline
\end{tabular}

1 Analyzed values.

2 One rat in this diet group died within 24 hours of receiving the experimental diet. 


\section{EXPERIMENT II}

EFFECT OF ATMOSPHERIC OXIDATION AND FORMALDEHYDE ON IRON BIOAVAILABILITY OF MECHANICALLY DEBONED BEEF

\section{Experimental Procedure}

\section{Meat Preparation}

Mechanically deboned uncooked beef was lyophilized. A portion of this meat was frozen until the diets were formulated. An additional portion of mechanically deboned, lyophilized, uncooked beef was spread evenly to a depth of approximately $5 \mathrm{~mm}$ on plastic trays and allowed to oxidize at $20-22^{\circ} \mathrm{C}$ for 14 days. This meat was then used in the preparation of the experimental diets.

\section{Preparation of Diets}

A low-iron diet and thirteen experimental diets were prepared. Stainless steel equipment which was cleaned and rinsed with deionized water was utilized in the preparation of the diets. The diet ingredients were mixed in an electric mixer with an epoxy coated bowl and paddle. Ingredients were measured to the nearest gram.

A low-iron diet was prepared to again aid in developing iron deficiency. It contained (in $\mathrm{g} / \mathrm{kg}$ diet): casein, $200 \mathrm{~g}$; dextrose, $485 \mathrm{~g}$; rendered beef fat, $200 \mathrm{~g}$; a-cellulose, $25 \mathrm{~g}$; vitamin mixture, $20 \mathrm{~g}$ (Table 1); $\mathrm{NaHPO}_{4}, 42.8 \mathrm{~g} ; \mathrm{CaCO}_{3}, 15.6 \mathrm{~g}$; and trace mineral mixture, $11.6 \mathrm{~g}$ (Table 5). The experimental diets were prepared, differing in percentages of fresh meat, oxidized meat, casein (basal) diet, $\mathrm{FeSO}_{4}$ and formaldehyde (Table 6). 
Table 5. Mineral mixture added to diets used in determining iron bioavailability of mechanically deboned oxidized beef

\begin{tabular}{lccc}
\hline \multicolumn{1}{c}{ Salt } & g salt/kg mixture & Mineral & mg mineral/kg diet \\
\hline $\mathrm{KCl}$ & 296.9 & $\mathrm{~K}$ & 1,806 \\
$\mathrm{MgCO}_{3}$ & 121.0 & $\mathrm{Mg}$ & 404 \\
$\mathrm{ZnSO}_{4} \cdot 7 \mathrm{H}_{2} \mathrm{O}$ & 38.0 & $\mathrm{Zn}$ & 100 \\
$\mathrm{MnSO}_{4} \cdot \mathrm{H}_{2} \mathrm{O}$ & 12.7 & $\mathrm{Mn}$ & 47.9 \\
$\mathrm{CuSO}_{4}$ & 1.0 & $\mathrm{Cu}$ & 3.0 \\
$\mathrm{KI}$ & 0.8 & $\mathrm{I}$ & 2.2 \\
$\mathrm{CoCL}_{2} \cdot 6 \mathrm{H}_{2} \mathrm{O}$ & 0.7 & $\mathrm{Co}$ & 2.01 \\
\hline
\end{tabular}

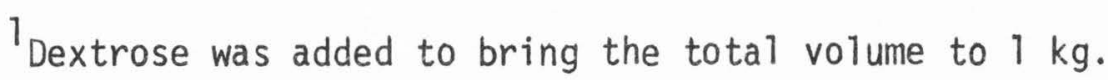

Anima1s and Animal Care

A total of 126 weanling, male Sprague Dawley rats (obtained from Simonsen Laboratories, Gilroy, California) were housed individually in stainless steel cages in a temperature controlled room. The rats were fed the low-iron casein diet (12.8 ppm Fe) ad libitum for ten days. About $0.7 \mathrm{cc}$ blood was taken by capillary tube from the retro-ocular capillary bed on the third and eighth days to increase the anemic condition.

On day 10 the rats were weighed and hemoglobin measures taken. Then the rats were assigned to 14 groups of nine each so that mean hemoglobin concentration and mean body weight were similar. The experimental diets were fed to the rats according to the following schedule: $8 \mathrm{~g}$ on day $1,7 \mathrm{~g}$ on day 2, $6 \mathrm{~g}$ on days 3-10. Any food not consumed was weighed back daily. The total diet consumed was calculated and recorded. Demineralized water was allowed ad libitum 
during both the low-iron casein diet and the experimental diets.

Table 6 . Composition of diets in experiment 2

\begin{tabular}{|c|c|c|c|}
\hline Diet & Fe Added ${ }^{\top}$ & $\mathrm{CH}_{2} \mathrm{O}$ Added $^{2}$ & $\mathrm{Fe} \mathrm{ppm}^{3}$ \\
\hline Basal (casein) & - & - & 12.8 \\
\hline Basal & $10 \mathrm{ppm}$ & - & 23.6 \\
\hline Basal & $20 \mathrm{ppm}$ & - & 35.2 \\
\hline Basal & $20 \mathrm{ppm}$ & 40 ppm & 32.3 \\
\hline Basal & $20 \mathrm{ppm}$ & 80 ppm & 30.3 \\
\hline Basal & $40 \mathrm{ppm}$ & - & 48.2 \\
\hline Basal & 40 ppm & 80 ppm & 49.1 \\
\hline $100 \%$ fresh beef & - & - & 26.0 \\
\hline $\begin{array}{l}75 \% \text { fresh beef } \\
25 \% \text { oxidized beef }\end{array}$ & - & - & 24.1 \\
\hline $\begin{array}{l}50 \% \text { fresh beef } \\
50 \% \text { oxidized beef }\end{array}$ & - & - & 23.7 \\
\hline $\begin{array}{l}25 \% \text { fresh beef } \\
75 \% \text { oxidized beef }\end{array}$ & - & - & 23.6 \\
\hline $100 \%$ oxidized beef & - & - & 22.6 \\
\hline $100 \%$ fresh beef & - & $40 \mathrm{ppm}$ & 25.8 \\
\hline $100 \%$ fresh beef & - & 80 ppm & 26.0 \\
\hline
\end{tabular}

I Iron added as $\mathrm{FeSO}_{4} \cdot 7 \mathrm{H}_{2} \mathrm{O}$.

${ }^{2}$ Formal dehyde

${ }^{3}$ Iron content by analysis

Body weights and hemoglobin values were again measured at the conclusion of the ten day experimental feeding period. The rats were killed by decapitation. The livers were weighed, individually packaged in cellophane, labelled, and frozen for later iron analysis. 


\section{Analytical}

The lipid content of the meat was determined by using the Soxhlet method (Appendix B). Meats, diets, and 1ivers were charred in procelain crucibles and then ashed at $500-600^{\circ} \mathrm{C}$ for 24 hours. The ash residue of each was solubilized with $10 \mathrm{ml} 6 \mathrm{~N} \mathrm{HCl}$, heated to boiling, transferred to acid washed plastic bottles, and diluted to $25 \mathrm{ml}$ with demineralized water. These samples were analyzed for iron content by atomic absorption spectrophotometry at $2483 \stackrel{\circ}{A}$ using an air-acetylene flame. Triplicate determinations were analyzed on meat and diet samples. Hemoglobin $(\mathrm{Hb})$ concentrations were measured in duplicate samples of fresh blood using the cyanmethemoglobin method (Crosby et al., 1954). The amount of iron gained as hemoglobin was calculated assuming that $6.7 \%$ of the body weight reflects blood volume and that the iron concentration of hemoglobin is $3.35 \mathrm{mg} / \mathrm{g}$.

\section{Statistical Analysis}

The data were analyzed by analysis of variance. When treatment "F" was statistically significant $(P<0.05)$, least significant difference (LSD) values were calculated (Carmer and Swanson, 1973).

\section{Results}

\section{Meat Composition}

The lyophilized fresh mechanically deboned beef (less than $5 \%$ moisture) contained $56 \mathrm{mg} F \mathrm{Fe}$ and $598 \mathrm{~g}$ fat per $\mathrm{kg}$. The Tyophilized oxidized beef contained $55 \mathrm{mg} F e$ and $573 \mathrm{~g}$ fat per $\mathrm{kg}$.

\section{Animal Responses}

The body weight gain and the liver weights of the anemic rats fed 
the lyophilized oxidized beef diets and the diets containing formaldehyde are shown in Table 7. The body weight gain increased significantly $(P<0.05)$ with the addition of iron to the basal diet (groups $1-3,6)$. However, the addition of formaldehyde to the basal diet did not significantly affect body weight gain (groups $3-7$ ). The body weight gain was decreased $(P<0.01)$ as oxidized beef was combined with fresh beef in increasing proportions (groups 8-12). Although the addition of formladehyde to the fresh beef did cause a decrease in body weight, the decrease was not statistically significant (groups $8,13,14$ ).

Liver size increased $(P<0.05)$ as the proportion of oxidized beef in the diet increased (groups 8-11) with the exception of the rats in group 12 fed the $100 \%$ oxidized beef diet (Table 7 ). The animals in this diet group had livers that did not differ significantly in weight from the animals fed the 100\% fresh beef diet. However, the animals fed the $100 \%$ oxidized beef diet (group 12) lost an average of $14.4 \mathrm{~g}$ of body weight during the experiment. When liver size expressed as percent body weight is used as the criteria for an enlarged liver, the addition of oxidized beef to fresh beef in the diet resulted in significantly $(P<0.01)$ larger livers, including the rats fed the $100 \%$ oxidized beef diet. The addition of formaldehyde to the fresh beef diets (groups $8,13,14)$ resulted in a decrease $(P<0.05)$ in liver size. When liver size was calculated as percent of body weight, there was likewise a significant decrease in size. However, the pattern of decreased liver size did not continue as the amount of formaldehyde was increased. The addition of formaldehyde to the basal diets (groups 3-7) did not usually significantly alter the liver size. If significance occurred, no pattern to match the experimental design was evident. 
Table 7. Growth response of anemic male rats fed lyophilized mechanically deboned beef diets or diets containing formaldehyde

\begin{tabular}{|c|c|c|c|c|c|c|c|c|c|c|c|c|c|c|c|}
\hline Groun & 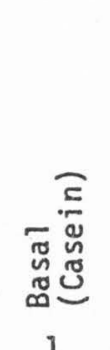 & 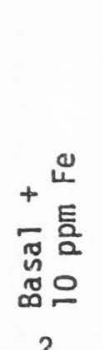 & 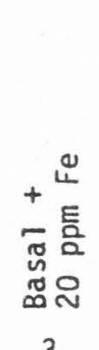 & 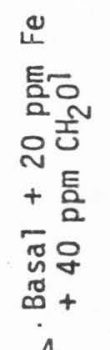 & 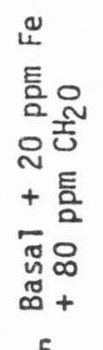 & 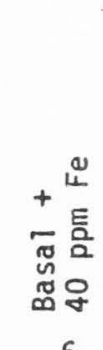 & 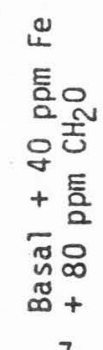 & 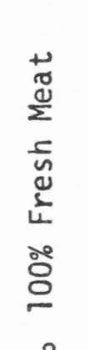 & 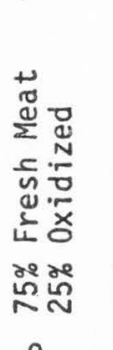 & 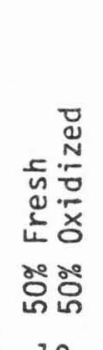 & 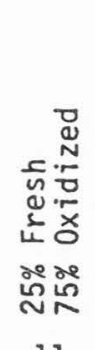 & 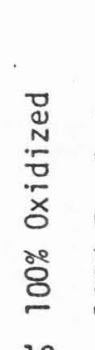 & 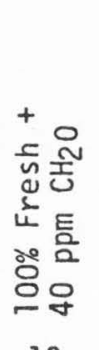 & 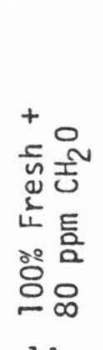 & \\
\hline Group & 1 & 2 & 3 & 4 & 5 & 6 & 7 & 8 & 9 & 10 & 11 & 12 & 13 & 14 & LSD $.05 / .01^{2}$ \\
\hline Dietary $\mathrm{Fe}, \mu \mathrm{g} / \mathrm{g}^{3}$ & 12.8 & 23.6 & 35.2 & 32.3 & 30.3 & 48.2 & 49.1 & 26.0 . & .24 .1 & 23.7 & 23.6 & 22.6 & 25.8 & 26.0 & \\
\hline No. of rats & 9 & 9 & 9 & 9 & 9 & 9 & 9 & 9 & 9 & 9 & 9 & 9 & 9 & 9 & \\
\hline BW initial, $g$ & 91.1 & 87.9 & 88.4 & 86.0 & 85.4 & 90.4 & 88.1 & 86.6 & 87.6 & 88.7 & 85.4 & 88.0 & 86.7 & 86.2 & NS \\
\hline BW gain, g & 7.2 & 9.9 & 14.4 & 13.7 & 11.1 & 13.6 & 14.5 & 14.3 & 15.3 & 8.2 & 0 & -14.4 & 15.9 & 10.2 & $5.7 / 7 / 6$ \\
\hline Liver, $g$ & 3.2 & 3.0 & 3.1 & 3.2 & 3.0 & 3.0 & 3.0 & 3.0 & 3.2 & 3.4 & 3.4 & 2.8 & 2.8 & 2.6 & $0.3 / 0.4$ \\
\hline Liver, $\%$ of BW & 3.3 & 3.1 & 3.0 & 3.2 & 3.7 & 2.9 & 2.9 & 3.0 & 3.2 & 3.5 & 3.9 & 3.7 & 2.7 & 2.8 & $0.2 / 0.3$ \\
\hline
\end{tabular}

Tormaldehyde.

${ }^{2}$ Mean differences must exceed the values indicated to be significantly different at the $5 \%$ or $1 \%$ levels of probability.

${ }^{3}$ Analyzed values. 
The hematinic responses of the rats fed the lyophilized oxidized beef diets or the diets containing formaldehyde are shown in Table 8 and summarized in Table 9. The gain in hemoglobin concentration (g/d1) was not significantly affected as oxidized beef was added to fresh beef (groups 8-12, see Tables 8 and 9). However, the iron gained as hemoglobin $(\mathrm{Hb}-\mathrm{Fe}, \mathrm{mg})$ decreased $(\mathrm{P}<0.01)$ as oxidized beef replaced fresh beef in the diet. In addition, the efficiency of converting dietary iron to hemoglobin iron ( $\mathrm{Hb}-\mathrm{Fe} / \mathrm{Fe}$ intake, $\mathrm{mg} / \mathrm{mg} \times 100$ ) decreased $(P<0.05)$ as oxidized beef replaced fresh beef in the diet. The liver iron content was not significantly affected in a consistent pattern as oxidized beef replaced fresh beef.

When formaldehyde was added to the fresh beef (groups 8, 13, 14), the gain in hemoglobin, the gain in hemoglobin concentration and the efficiency of conversion of food iron to hemoglobin iron were not significantly affected (Tables 8 and 9 ). However, liver iron concentration decreased significantly $(P<0.05)$ as did total liver iron $(P<0.01)$.

When iron was added to the basal diet (groups 1-3,6), the hematinic responses were increased $(P<0.01$ ) (Tables 8 and 9 ). When formaldehyde was added to the basal diet (groups 3-7), the hematinic responses were not significantly affected.

\section{Discussion}

Reduced weight gains were observed only in those rats fed severely oxidized beef (Table 7, groups 10-12). Miller and Landes (1975) and Greenberg and Fraser (1953) reported that rats fed severely oxidized soybean oil had reduced weight gains. Both groups of researchers also noted that relative liver weights were increased when severely 
Table 8. Hematinic responses of anemic male rats fed lyophilized mechanically deboned beef diets or diets containing formaldehyde

\begin{tabular}{|c|c|c|c|c|c|c|c|c|c|c|c|c|c|c|c|}
\hline Group & 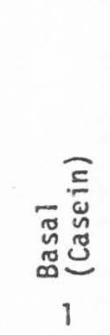 & 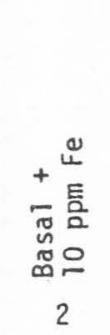 & 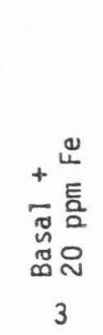 & 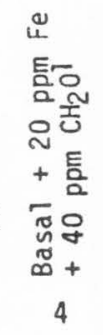 & 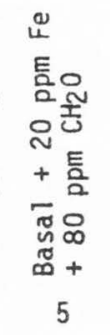 & 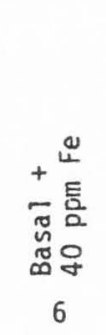 & 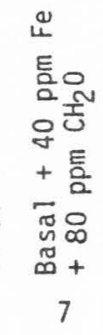 & 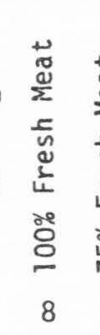 & 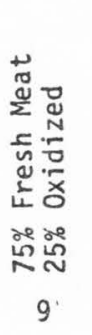 & 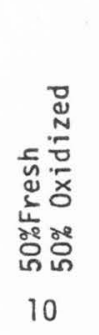 & 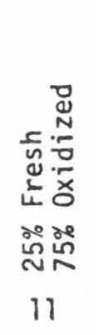 & 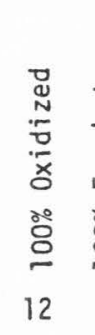 & 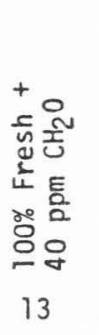 & 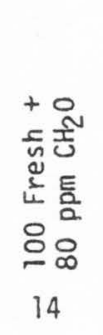 & LSD $.05 / .07^{2}$ \\
\hline Dietary $\mathrm{Fe} ; \mu \mathrm{g} / \mathrm{g}^{3}$ & 12.8 & 23.6 & 35.2 & 32.3 & 30.3 & 48.2 & 49.1 & 26.0 & 24.1 & 23.7 & 23.6 & 22.62 & 25.8 & 26.0 & \\
\hline No. of rats & 9 & 9 & 9 & 9 & 9 & 9 & 9 & 9 & 9 & 9 & 9 & 9 & 9 & 9 & \\
\hline $\mathrm{Fe}$ intake, $\mathrm{mg}$ & .73 & 1.43 & 2.12 & 1.99 & 1.83 & 3.00 & 2.96 & 1.69 & 91.54 & 1.48 & 1.38 & 81.16 & 61.68 & 1.64 & $0.10 / 0.14$ \\
\hline Hb initial, $g / d l$ & 5.27 & 5.45 & 5.65 & 5.33 & 5.32 & 5.35 & 5.35 & 5.58 & 85.50 & 5.47 & 5.67 & 75.33 & 35.32 & 5.28 & NS \\
\hline Hb gain, g/dl & 1.78 & 2.97 & 4.99 & 5.86 & 5.60 & 7.80 & 8.09 & 2.88 & 83.00 & 2.84 & 2.77 & 72.93 & 32.93 & 2.89 & $0.82 / 1.09$ \\
\hline $\mathrm{Hb} / \mathrm{Fe}$ gain, mg & 0.48 & 0.78 & 1.36 & 1.47 & 1.34 & 1.98 & $3 \quad 2.05$ & 0.83 & $\begin{array}{ll}30.88 \\
\end{array}$ & 0.72 & 0.54 & 40.35 & 50.87 & 0.76 & $0.21 / 0.27$ \\
\hline $\begin{array}{c}\mathrm{Hb}-\mathrm{Fe} / \mathrm{Fe} \text { intake, } \\
\mathrm{mg} / \mathrm{mg} \times 100\end{array}$ & 66.6 & 54.1 & 61.1 & 73.7 & 73.4 & 65.9 & 69.3 & 49.3 & 56.8 & 48.8 & 38.6 & 32.4 & 51.9 & 38.5 & $13.1 / 17.5$ \\
\hline Liver $\mathrm{Fe}, \mu \mathrm{g} / \mathrm{g}$ & 44 & 51 & 64 & 67 & 55 & 67 & 64 & 67 & 52 & 53 & 57 & 60 & 59 & 55 & $11.0 / 15.0$ \\
\hline Liver Fe, $\mu \mathrm{g}$ & 138 & 154 & 199 & 208 & 169 & 198 & 193 & 204. & 162 & 176 & 190 & 168 & 180 & 149 & $36 / 47$ \\
\hline
\end{tabular}

Tormaldehyde.

${ }^{2}$ Mean differences must exceed the values indicated to be significantly different at the $5 \%$ or $1 \%$ levels of probability.

${ }^{3}$ Analyzed values. 
Table 9. Summary of hematinic responses of anemic male rats fed lyophilized mechanically deboned beef diets or diets containing formaldehyde

\begin{tabular}{|c|c|c|c|c|}
\hline $\begin{array}{l}\text { Hematinic } \\
\text { Measure }\end{array}$ & $\begin{array}{l}\text { Basal Diet } \\
\text { Increase Fe }\end{array}$ & $\begin{array}{l}\text { Basal Diet } \\
\text { Increase } \\
\mathrm{CH}_{2} \mathrm{O}\end{array}$ & $\begin{array}{l}\text { Meat Diet } \\
\text { Increase } \\
\% \text { Oxid.2 }\end{array}$ & $\begin{array}{l}\text { Meat Diet } \\
\text { Increase } \\
\mathrm{CH}_{2} \mathrm{O}\end{array}$ \\
\hline Hb gain, g/dl & $\uparrow(.01)$ & No pattern & NS & NS \\
\hline $\mathrm{Hb}-\mathrm{Fe}$ gain, mg & $\uparrow(.01)$ & NS & $\downarrow(.01)$ & NS \\
\hline $\mathrm{Hb}-\mathrm{Fe} / \mathrm{Fe}$ intake & No Change (NS) & NS & $\downarrow(.05)$ & NS \\
\hline Liver $\mathrm{Fe}, \mu \mathrm{g} / \mathrm{g}$ & $\uparrow(.01)$ & NS & No pattern & $\downarrow(.05)$ \\
\hline Liver $\mathrm{Fe}, \mu \mathrm{g}$ & $\uparrow(.01)$ & NS & No pattern & $\downarrow(.01)$ \\
\hline
\end{tabular}

TFormaldehyde.

2 Mechanically deboned, uncooked beef was lyophilized. A portion of the mechanically deboned, 1yophilized, uncooked beef was allowed to oxidize at $20^{\circ}-22^{\circ} \mathrm{C}$ for 14 days. The beef diets were then made in the following proportions: $100 \%$ fresh, beef, $75 \%$ fresh $-25 \%$ oxidized beef, $50 \%$ fresh - $50 \%$ oxidized beef, $25 \%$ fresh $-75 \%$ oxidized beef, and 100\% oxidized beef.

oxidized soybean oil was fed, although not significantly in the Greenberg and Fraser (1953) study. In the present study, rats fed the severely oxidized beef meat (Table 7, groups 9-12) had increased relative liver weights. Formaldehyde addition to the basal diet did not affect relative liver weight. However, the addition of formaldehyde to the fresh meat diet resulted in decreased relative liver weight in rats.

The assay of iron bioavailability based upon the efficiency of converting food iron into hemoglobin iron enabled the detection of oxidation effects of meat iron bioavailability in this study (Tables 7,8 and 9). When a low-iron basal diet is supplemented with iron 
(groups $1,2,3$, and 6 ), the gain in hemoglobin concentration and the gain in hemoglobin increased as expected (Mahoney and Hendricks, 1976). Further, in agreement with earlier reports (Mahoney et al., 1974, Mahoney and Hendricks, 1976), the efficiency of the conversion of dietary iron to hemoglobin iron remained practically constant over the range of dietary iron levels; this is a characteristic of a valid assay. With this procedure, it was found that the bioavailability of iron of oxidized meat was depressed (group 12 versus 8). Adding $80 \mathrm{ppm}$ formaldehyde to the fresh meat diet (group 14 versus 8 and 13) also depressed meat iron bioavailability. These differences are not apparent if changes in hemoglobin concentration are used as criteria for the evaluation of iron bioavailability. As pointed out earlier (Mahoney et a1., 1974), when differences in animal growth occur as in this study, the efficiency of converting food iron into hemoglobin iron would be the criterion of choice.

Only those rats fed lyophilized beef that had been oxidized at $20-22^{\circ} \mathrm{C}$ for 14 days had impaired iron metabolism (Table 8, group 12). The liver iron content of these rats was also reduced. This finding is in agreement with those of Miller and Landes (1975) who observed that rats fed either aerated or heated soybean $0 i 1$ had reduced hemoglobin concentrations, hematocrit values, and decreased liver iron stores.

Although the addition of formaldehyde to the fresh lyophilized beef diet reduced the efficiency of converting meat iron to hemoglobin iron and reduced the iron content of the liver (Table 8, group 14 versus 8 ), this did not occur in the rats fed the basal diet supplemented with ferrous sulfate (Table 8 , groups 7 versus 6 and 5 versus 3 ). A possible reason for this effect is that fresh lyophilized beef 
may have contained some endogenous formaldehyde. Thus, the formaldehyde content of the meat diet fed group 14 would include that naturally present in the product plus that added, while the formaldehyde content of the basal diets would have reflected only that added. An alternative reason for this effect is that other oxidation products (Gray, 1978) in the meat, such as aldehydes, ketones, glycols and dicarboxylic acids potentially present in the lyophilized beef, might have contributed to reduced bioavailability of meat iron. But the formaldehyde added to the basal diets might have interacted with the casein present making it unavailable to affect iron metabolism in rats fed these diets. Formaldehyde readily interacts with free amino groups and has been used industrially to harden casein (Haurowitz, 1963). On the other hand, added formaldehyde might have interacted with the organic iron compounds in meat to decrease iron bioavailabiłity but did not interact with the inorganic ferrous sulfate in the casein diets.

Formaldehyde values were determined for the turkey meat in experiment 1. An attempt was made to determine formaldehyde values for the beef and basal diets in experiment 2. Even when formaldehyde was added to the basal or beef diets, little formaldehyde was recovered analytically. This might be due to formaldehyde reacting with free amino groups (Haurowitz, 1963). The formaldehyde contents of the oxidized beef diets were $5.6,15,26.3,35.8$ and $41 \mathrm{ug} / \mathrm{g}(y=0.0269 x-$ $0.1662, r=0.99)$, respectively, for groups 8-12. The formaldehyde values for the oxidized beef were lower than for the oxidized turkey if the turkey formaldehyde data are extrapolated to a similar length of oxidation time. As turkey fat has a higher percentage of unsaturated fat than beef fat, one would expect the formaldehyde values for 
the turkey to be higher than for the beef. Thus far, it has been our hypothesis that increased oxidation of meat resulted in decreased bioavailability of iron. Oxidation, as measured by formaldehyde values, does not seem to be an appropriate predictor of decreased bioavailability of iron across meat diets from different species.

Although formaldehyde has been associated with oxidized fat, it is not likely that it is the only chemical moiety affecting hematinic responses and relative liver size. Some hematinic responses were depressed when rats were fed fresh, lyophilized beef diets to which formaldehyde had been added (Table 8, group 8 versus groups 13-14 and Table 9). However, different hematinic responses were depressed when rats were fed diets high in oxidized beef (Table 8, groups 9-12 and Table 9). Furthermore, the addition of formaldehyde to fresh, 1 yophilized beef diets resulted in rats with decreased relative liver weights (Table 8, groups 13-14). In contrast, rats fed diets high in oxidized beef had increased relative liver weights (Table 8, groups 9-12 and Table 9). As formaldehyde is not the only aldehyde formed as a result of oxidation, it may be that other aldehydes may be more involved in affecting iron bioavailability than formaldehyde. Possibly this may explain the above results.

In this experiment mechanically deboned, lyophilized, uncooked beef diets caused decreased body growth, enlarged livers, and a depression of some measures of hematinic response in growing rats. 


\section{EXPERIMENT III}

A COMPARISON OF THE EFFECT OF ATMOSPHERIC OXIDATION ON HAND DEBONED AND MECHANICALLY DEBONED LYOPHILIZED TURKEY MEAT AND HAND DEBONED AND MECHANICALLY DEBONED LYOPHILIZED BEEF MEAT

\section{Experimental Procedure}

\section{Meat Preparation}

Hand deboned dark turkey (HDT) meat was obtained from the Moroni Processing Co., Moroni, Utah. The dark turkey meat was taken directly off the boning line at the meat processor's plant. It was frozen, sliced in approximately $1.9 \mathrm{~cm}$ slices and lyophilized.

Mechanically deboned turkey (MDT) meat was likewise obtained from the Moroni Processing Co., Moroni, Utah. Whole turkey frames were used in the mechanical deboning. A Beehive AU-4171 Mechanical Deboner with a 0.031 inch $(0.787 \mathrm{~mm})$ perforated cylinder was used for the deboning. After mechanical deboning, the turkey meat was frozen, sliced into approximately $1.9 \mathrm{~cm}$ slices, and lyophilized. Hand deboned beef (HDB) was obtained through the Utah State University Meat Laboratory, Logan, Utah. It was ground, frozen, sliced, and lyophilized.

Mechanically deboned beef (MDB) was obtained from the University of Wyoming Meat Laboratory, Laramie, Wyoming. The beef bones with adhering meat were fed through a BA-8 Beehive Bone Cutter. An AUX705 Beehive Mechanical Deboner equipped with an AUX-705 0.018 inch head ( $0.457 \mathrm{~mm}$ perforations) was used for the deboning. The mechanical$1 y$ deboned beef was frozen, sliced and 1yophilized.

The above lyophilized meat samples were ground after lyophilization. 
The hand deboned beef and mechanically deboned turkey were ground using a plate with $2 \mathrm{~mm}$ to $3 \mathrm{~mm}$ perforations. The hand deboned turkey and mechanically deboned beef were ground using a plate with $6 \mathrm{~mm}$ performations. The coarser grinding plate was used for the last two samples ground, because the mechanically deboned turkey had become stuck in the machinery, causing a power failure and the meat grinder to 1ock.

The uncooked, lyophilized, ground meat was spread evenly to a depth of approximately $5 \mathrm{~mm}$ on plastic trays and allowed to oxidize at $20-22^{\circ} \mathrm{C}$ for 0 hours and 336 hours. After the meat was exposed to the air the proper length of time, it was vacuum packed and stored in nitrogen atmosphere at $-20^{\circ} \mathrm{C}$ until the chemical analyses were completed.

\section{Analytical}

The micro-Kjeldahl method was used for determining the nitrogen content of the meat (Appendix A). The crude lipid analysis was made using the Soxhlet method (Appendix B). Malonaldehyde content of meat samples was analyzed using the Thiobarbituric Acid Method (Sinnhuber and Yu, 1958) (Appendix C). The Iodine Number (Daniel and Neal, 1967) (Appendix D) was used to measure the degree of unsaturation of the lipid in the meats. The abovedeterminations were done using triplicate samples.

\section{Statistical Analysis}

The data were analyzed by analysis of variance. When treatment " $F$ " was statistically significant $(P<.05)$, least significant difference (LSD) values were calculated (Carmer and Swanson, 1973). 


\section{Results}

The moisture, lipid, nitrogen and iron content of the uncooked, lyophilized ground meat samples are reported in Table 10. The hand deboned turkey contained $2.3 \%$ moisture, $15.9 \%$ crude 1 ipid, $74.8 \%$ crude protein, and $32.3 \mathrm{ppm}$ iron. The mechanically deboned turkey contained $3.5 \%$ moisture, $39.2 \%$ crude 1 ipid, $51.2 \%$ crude protein and $35.1 \mathrm{ppm}$ iron. The hand deboned beef contained $2.4 \%$ moisture, $46.5 \%$ crude lipid, $45.7 \%$ crude protein, and $28.4 \mathrm{ppm}$ iron. The mechanically deboned beef contained $2.4 \%$ moisture, $42.3 \%$ crude 1 ipid, $45.9 \%$ crude protein and $85.0 \mathrm{ppm}$ iron.

The TBA values (ug malonaldehyde/g) of the meat samples are shown in Table 11 and Figure 2. There was a significant difference $(P<.01)$ between 0 hours oxidation time and 336 hours oxidation time. Using the LSD it is noted that the TBA value increases significantly only for the mechanically deboned turkey. There is no significant difference in TBA values for varying oxidation times of hand deboned turkey, hand deboned beef, or mechanically deboned beef.

The turkey samples had significantly higher $(P<.01)$ TBA values than the beef samples as noted in Table 11 and Figure 2.

Significant differences for TBA values occurred between mechanical1y deboned and hand deboned samples. The mechanically deboned turkey oxidized for 336 hours had a significantly higher $(P<.05)$ TBA value than the hand deboned samples oxidized for 0 hours. There was no significant difference between TBA values for hand and mechanically deboned meat for turkey at 0 hours oxidation or beef at 336 hours oxidation time. 
Table 10. Analytical composition of uncooked, ground, lyophilized meat before oxidation

\begin{tabular}{ccccc}
\hline \multicolumn{1}{c}{ Meat } & $\begin{array}{c}\text { Mositure } \\
(\%)\end{array}$ & $\begin{array}{c}\text { Crude } \\
\text { Lipid } \\
(\%)\end{array}$ & $\begin{array}{c}\text { Crude Protein } \\
(\%)\end{array}$ & $\begin{array}{c}\text { Iron } \\
(\text { ppm })\end{array}$ \\
\hline Hand Deboned Turkey & 2.3 & 15.9 & 74.8 & 32.3 \\
Mechanical1y Deboned Turkey & 3.5 & 39.2 & 51.2 & 35.1 \\
Hand Deboned Beef & 2.4 & 46.5 & 45.7 & 28.4 \\
Mechanical1y Deboned Beef & 2.4 & 42.3 & 45.9 & 85.0 \\
\hline
\end{tabular}

Table 11. TBA values ( $\mu \mathrm{g}$ malonalabhyde/g) of meat samples before and after oxidation

\begin{tabular}{lccc}
\hline $\begin{array}{c}\text { Meat } \\
\text { Treatment }\end{array}$ & 0 Hour Oxidation & $\begin{array}{c}\text { 336 Hours } \\
\text { Oxidation }\end{array}$ & $\begin{array}{c}\text { LSD } \\
.05 / .01\end{array}$ \\
\hline Hand Deboned Turkey & 7.1 & 7.8 & $0.9 / 1.2$ \\
$\begin{array}{l}\text { Mechanical1y Deboned } \\
\text { Turkey }\end{array}$ & 7.0 & 9.8 & \\
$\begin{array}{l}\text { Hand Deboned Beef } \\
\begin{array}{l}\text { Mechanically Deboned } \\
\text { Beef }\end{array}\end{array}$ & 1.7 & 2.6 & 2.8 \\
\hline
\end{tabular}




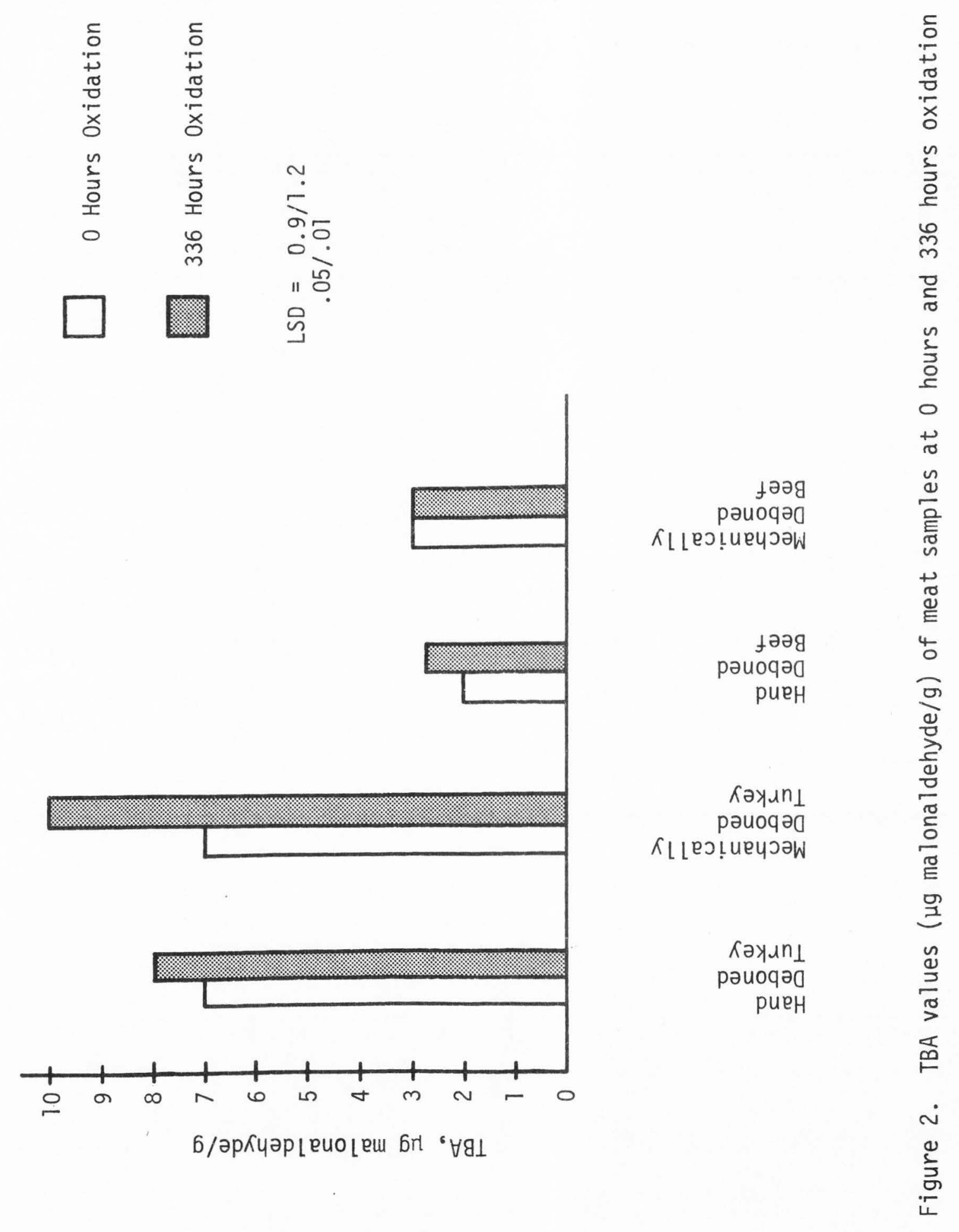


The iodine number was calculated in two ways. First it was calculated as $\mathrm{I}_{2}$ absorbed per $100 \mathrm{~g}$ sample (Table 12 and Figure 3). Second it was calculated as $\mathrm{I}_{2}$ absorbed per $100 \mathrm{~g}$ fat (Table 13 and Figure 4).

When the iodine number was calculated as $\mathrm{g} \mathrm{I}_{2}$ absorbed per $100 \mathrm{~g}$ sample, there were no significant differences between samples oxidized 0 hours and 336 hours.

There were significant differences $(P<.01)$ in iodine numbers between the turkey and beef meat. The mechanically deboned beef oxidized for 0 hours had a significantly lower $(P<.01)$ iodine number than the turkey samples oxidized for 0 hours. Likewise, the mechanical1y deboned beef oxidized for 336 hours had a significantly lower $(P<.01)$ iodine number than the turkey samplesoxidized similarly. However, there were no significant differences between the iodine numbers for hand deboned beef at 0 hours or 336 hours oxidation time and the turkey samples oxidized identically.

There were no significant differences in iodine number of hand deboned or mechanically deboned turkey at either 0 hours oxidation or 336 hours oxidation time. Likewise, there was no significant difference in iodine number between hand deboned and mechanically deboned beef that had been allowed to oxidize 0 hours. However, oxidized mechanically deboned beef had an iodine value which was significantly lower $(P<.01)$ than the iodine value for oxidized hand deboned beef. When the iodine number was calculated as $\mathrm{g} \mathrm{I}_{2}$ absorbed per $100 \mathrm{~g}$ fat (Table 13 and Figure 4), there were no significant differences between samples oxidized 0 hours and 336 hours. Again there were significant differences $(P<.01)$ in iodine values between the turkey 
Table 12. Iodine number (calculated as grams $I_{2}$ absorbed per $100 \mathrm{~g}$ sample) of meat samples before and after oxidation

\begin{tabular}{lccc}
\hline $\begin{array}{c}\text { Meat } \\
\text { Treatment }\end{array}$ & $\begin{array}{c}\text { Iodine Number } \\
\text { 0 Hours Oxidation }\end{array}$ & $\begin{array}{c}\text { Iodine Number } \\
336 \text { Hours Oxidation }\end{array}$ & $\begin{array}{c}\text { LSD } \\
.05 / .01\end{array}$ \\
\hline $\begin{array}{l}\text { Hand Deboned } \\
\text { Turkey }\end{array}$ & 41.0 & 41.5 & $4.1 / 5.8$ \\
$\begin{array}{l}\text { Mechanically } \\
\text { Deboned Turkey }\end{array}$ & 43.5 & 40.5 & 39.6 \\
$\begin{array}{l}\text { Hand Deboned } \\
\text { Beef }\end{array}$ & 38.3 & 31.0 \\
$\begin{array}{l}\text { Mechanically } \\
\text { Deboned Beef }\end{array}$ & 34.5 & & \\
\hline
\end{tabular}

Table 13. Iodine number (calculated as $\mathrm{g} \mathrm{I} \mathrm{I}_{2}$ absorbed per $100 \mathrm{~g}$ fat in sample) of meat samples before and after oxidation

\begin{tabular}{lccc}
\hline $\begin{array}{c}\text { Meat } \\
\text { Treatment }\end{array}$ & $\begin{array}{c}\text { Iodine Number } \\
\text { 0 Hours Oxidation }\end{array}$ & $\begin{array}{c}\text { Iodine Number } \\
336 \text { Hours Oxidation }\end{array}$ & $\begin{array}{c}\text { LSD } \\
.05 / .01\end{array}$ \\
\hline $\begin{array}{l}\text { Hand Deboned } \\
\text { Turkey }\end{array}$ & 257 & 263 & $17 / 24$ \\
$\begin{array}{l}\text { Mechanical1y } \\
\text { Deboned Turkey }\end{array}$ & 111 & 104 & \\
$\begin{array}{l}\text { Hand Deboned } \\
\text { Beef }\end{array}$ & 83 & 86 & \\
$\begin{array}{l}\text { Mechanically } \\
\text { Deboned Beef }\end{array}$ & 82 & 74 \\
\hline
\end{tabular}


ปั

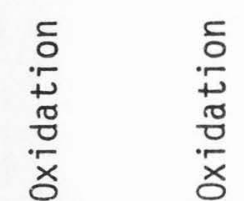

岂

๗ำ

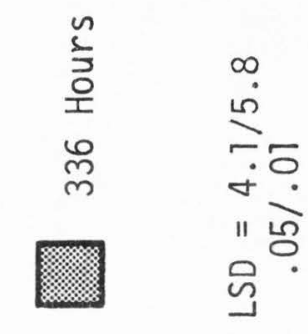

$\infty$
0
0
+0
1150
0

๕ั)

o

$\square$
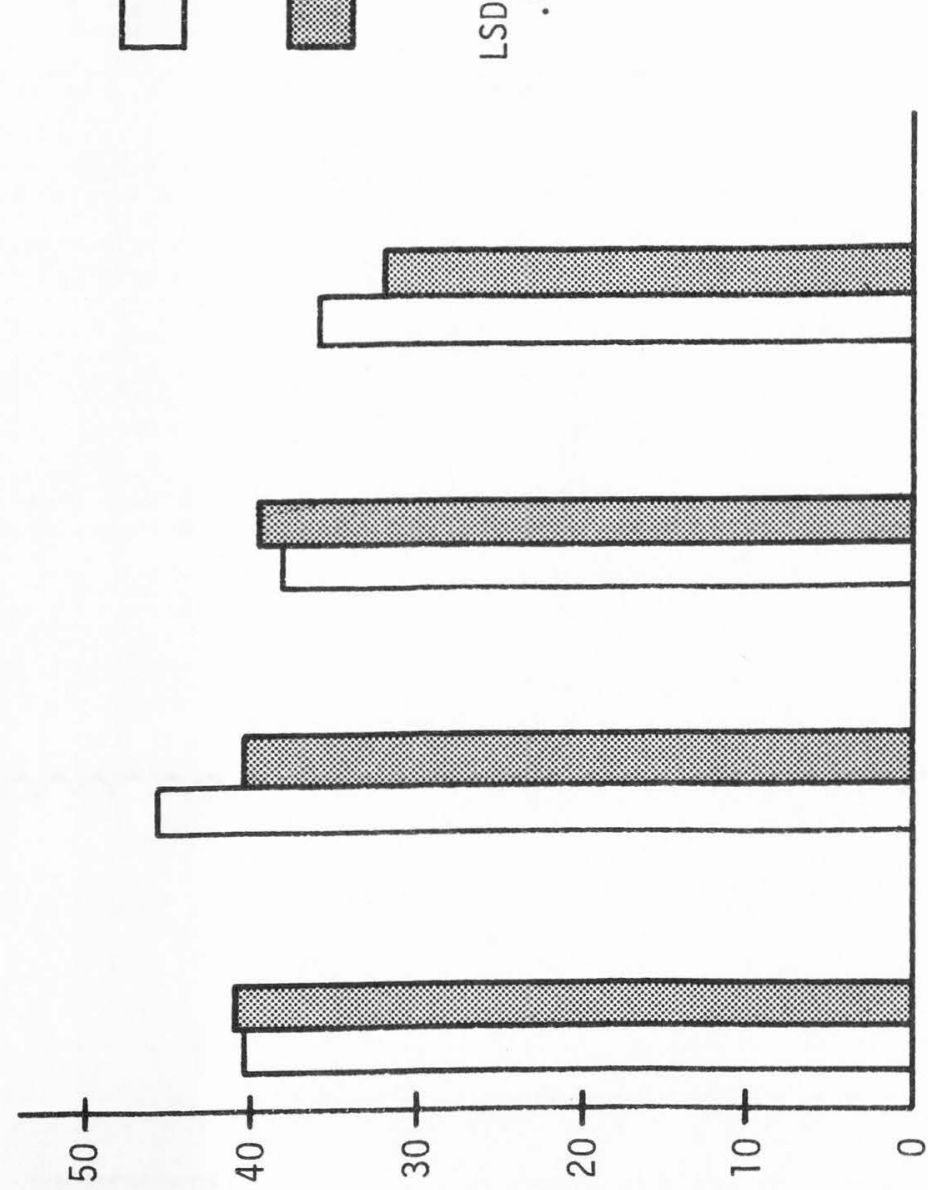

Kəxun!

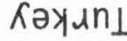

เววg

рәиоqә0

КLLеว!นецวаW

рәиоqә0

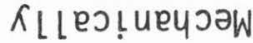

рәuоqә0

pueH

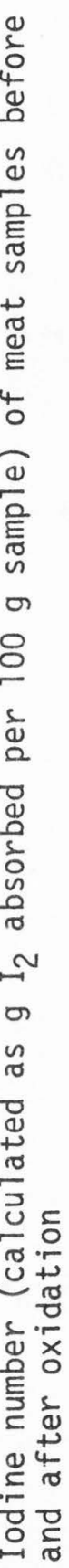

$\dot{m}$
$\frac{0}{5}$
ㅁํㄴ 


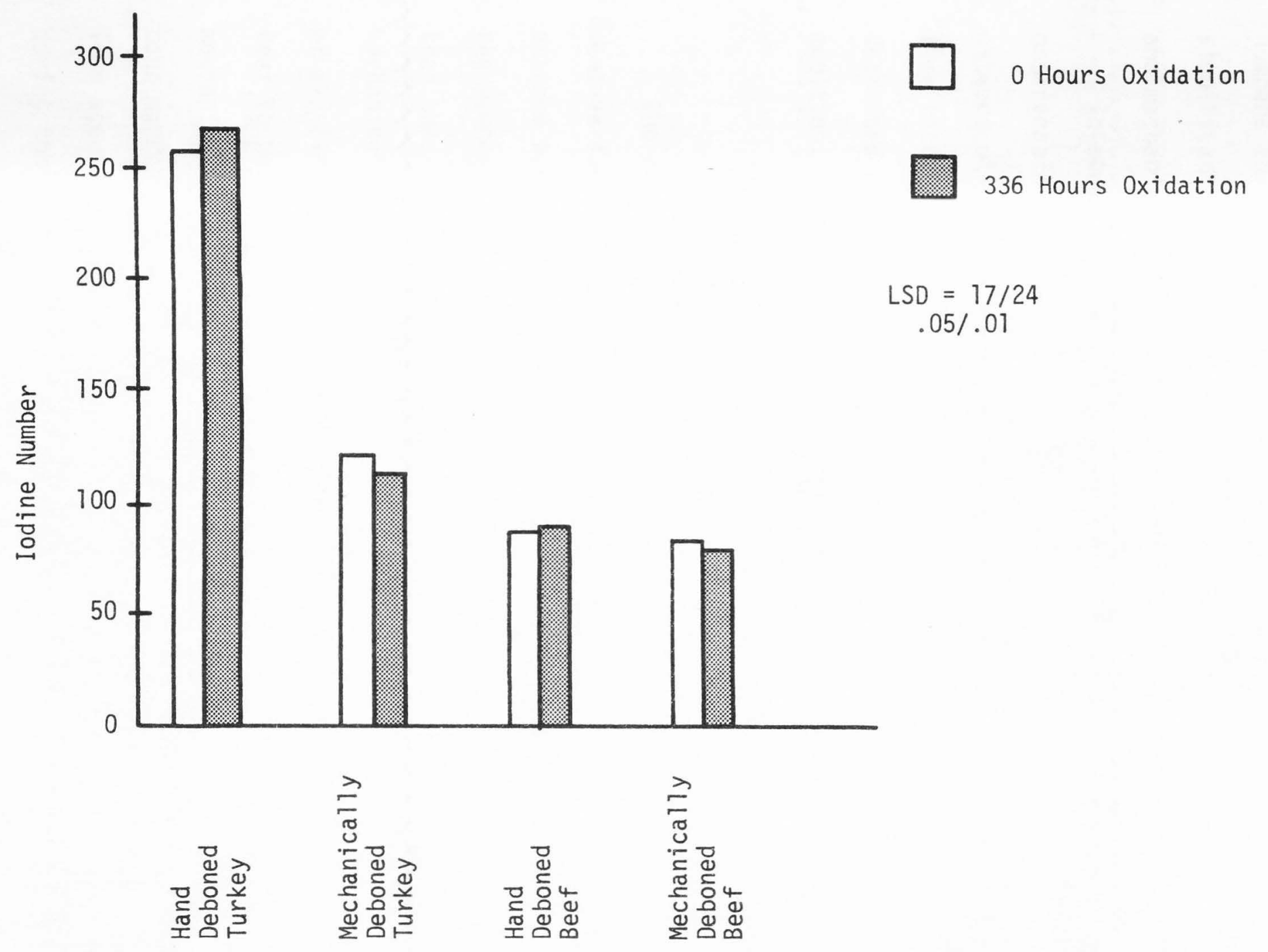

Figure 4. Iodine number (calculated as $\mathrm{g} \mathrm{I}_{2}$ absorbed per $100 \mathrm{~g}$ fat in sample) of meat samples before and after oxidation 
and beef meat. The turkey samples had significantly higher $(P<.01)$ iodine numbers than the beef samples.

The hand deboned turkey had significantly higher $(P<.01)$ iodine numbers than the mechanically deboned turkey. However, there were no significant differences between the iodine numbers for hand deboned and mechanically deboned beef.

In addition to the results reported above, there were some very observeable changes in the meat as oxidation time increased. No attempt was made to measure these changes. As oxidation time increased the coloring of the meat became brownish. With decreased oxidation periods, the meat remained reddish in color. In addition, with increased oxidation time, the meat increased in odor.

\section{Discussion}

The analytical composition of the uncooked, lyophilized, ground meat varied interestingly. The hand deboned beef and mechanically deboned beef had similar moisture, lipid, and protein values. However, the mechanically deboned beef had much higher iron values (85 ppm) than the hand deboned beef (28.4 ppm) (Table 10). As a comparison, mechanically deboned beef in experiment 2 contained $55 \mathrm{ppm}$ iron. Farmer et a1. (1977) found the iron content of mechanically deboned shank beef to be $93.1 \mathrm{ppm}$ and suggested that the increased iron values for mechanically deboned meat might be attributed to the incorporation of bone marrow into the final product during the deboning process or to iron accumulated in the mechanically deboned meat from the equipment during the deboning process. At any rate increased levels of iron in mechanically deboned beef have been confirmed. 
Both hand deboned turkey and mechanically deboned turkey had low percentages of moisutre, $2.3 \%$ and $3.5 \%$ respectively. However, the lipid and protein content of the turkey samples varied greatly. The hand deboned turkey contained much less fat (15.9\%) than the mechanically deboned turkey (39.2\%). As the turkey was being hand deboned, the leaner meat from the breast and legs would be removed. When the whole turkey frames are used for mechanical deboning, much of the fat remains on the frame. Thus, hand deboned turkey would have a lower percentage of fat and higher percentage of protein. Conversely, mechanically deboned turkey would have a higher percentage of fat and lower percentage of protein. Alired (1976) found hand deboned turkey to have $10.8 \mathrm{ppm}$ iron and mechanically deboned turkey to have 18.8 ppm iron. Our data showed a much higher iron leve1; hand deboned turkey $32.3 \mathrm{ppm}$ iron and mechanically deboned turkey $35.1 \mathrm{ppm}$ iron. In both instances the mechanically deboned turkey had higher iron levels. This might be attributed to the same reasons described above for the mechanically deboned beef having increased iron levels.

The mechanically deboned meat had increased levels of iron over the hand deboned meat. However, the mechanically deboned beef had a much greater increase in iron over the hand deboned beef than the mechanically deboned turkey had over the hand deboned turkey. As the bones of beef are much larger than turkey bones, more abrassion takes place when they are processed in the bone cutter. Consequently, more iron would be accumulated from the equipment during the deboning process for beef than for turkey.

The presence of malonaldehyde in food products has been associated with rancidity or oxidation in foods (Sinnhuber and Yu, 1958). 
Malonaldehyde has been detected in a variety of food including raw ground beef (Hutchins et a1., 1967) and cooked meats (Tarladgis et al., 1960; Shamberger et a1., 1977). During the oxidation process, unsaturated fatty acids are broken down to a variety of low molecular weight compounds including malonaldehyde. As meat contains varying degrees of unsaturated fatty acids, it would be expected that during an increased oxidation period, degeneration of the unsaturated fatty acids would result in increased amounts of malonaldehyde. However, in this experiment an increased oxidation period resulted in significantly higher levels of malonaldehyde as measured by the TBA value for only mechanically deboned turkey. Increased oxidation time did not significantly increase TBA values in hand deboned turkey, hand deboned beef, or mechanically deboned beef. It is possible that oxidative degeneration had taken place preceeding the experimental oxidation period and had stabilized. Also, as malonaldehyde forms compounds with free amino groups (Fennema, 1976), this may have occurred in this experiment.

The turkey samples had significantly higher $(P<.01)$ TBA values than the beef samples (Table 11 and Figure 2). Poultry lipids have been found to be more unsaturated than those of red meat (Lea, (1938). Hence, it would be expected that the turkey meat would have higher TBA values than the beef. Shamberger et al. (1977) have published malonaldehyde contents of beef and turkey. Although it is difficult to compare TBA values with certainty from laboratory to laboratory, Shamberger found high levels of malonaldehyde in uncooked turkey $(10.8 \mu \mathrm{g} / \mathrm{g})$ and general1y 
more moderate amounts in varying cuts of uncooked beef $(1.2 \mu \mathrm{g} / \mathrm{g}$ $7.2 \mu \mathrm{g} / \mathrm{g})$. Our findings would be consistent with these. In addition, the hand deboned, uncooked, lyophilized turkey samples used in Experiment 1 had initial TBA values (Figure 1) similar to the TBA values for the hand deboned, uncooked, lyophilized turkey in this experiment.

It would be assumed that with the pulverizing that takes place during mechanical deboning, increased surface areas would be available to oxidation, plus oxygen would be introduced during the mechanical deboning process. Hence, it would be expected that mechanical deboning would make fatty acids in the meat more susceptible to oxidation and result in degeneration of fatty acids to aldehydes, peroxides, dycols, ketones, and decarboxylic acids. Therefore, higher TBA values would be expected for mechanically deboned meat. In this experiment TBA values for mechanically deboned meats were higher for turkey oxidized 336 hours, beef oxidized 0 hours, and beef oxidized for 336 hours (Table 11 and Figure 2), although significantiy for only the turkey oxidized for 336 hours $(P<.01)$ and beef oxidized 0 hours $(P<.05)$. As the original hand deboned and mechanically deboned beef samples and turkey samples did not come from the same source, it is difficult to evaluate which other factors such as freshness, aging of beef, lipid content of feed, storage temperatures, etc. may have affected the initial oxidation and production of malonaldehyde for these meats. Consequently, an evaluation of mechanical versus hand deboning on TBA values is difficult to ascertain with the number of samples that we used, the possible diversity of initial handling, and the variability in the limited statistics 
in this study.

The TBA values obtained for uncooked, lyophilized, hand deboned turkey in Experiment 1 initially were higher than in Experiment 3 . This is partly because the TBA values in Experiment 1 were calculated by the formula Optical Density minus Blank times the factor (108) divided by the weight of the meat equals TBA value. Had the samples in Experiment 3 been calculated by the same formula, the TBA value for the samples in Experiment 3 would have been much higher. In Experiment 3 malonaldehyde standards were prepared, run through the method, optical densities read, a regression line calculated, and TBA values for the meats were calculated based on the malonaldehyde standards. It was expected that more significant differences between our meat samples would occur. It has been suggested that TBA value is not a reliable indicator in dry systems (Fennema, 1976). The procedure appears to have been successful for Andrews et a1. (1977) and in Experiment I. However, the results in Experiment III are questionable and might be related to the fact that a dry system was being tested.

Iodine or equivalent amounts of other halogens will add at double bonds of unsaturated fatty acids. If a known amount of a halogen is added at the beginning of a determination and time is allowed for the reagent to add at a11 double bonds in the fat molecule, then a determination of the remaining halogen will, by difference, give the amount of halogen combining with the fat. Hence, a highly unsaturated fat will have a high iodine number and a saturated fat will have a low iodine number. In using the iodine number, it was felt that the initial iodine number would give an indication of the degree of saturation of the fat. The meat samples 
would be allowed to oxidize for 336 hours at which time they would again be tested with the iodine number. If oxidation had taken place, there would be a decrease in the number of double bonds available for combination with the halogen. Hence, the meat sample would have a lower iodine number.

When the iodine number was calculated either as grams $I_{2}$ absorbed per $100 \mathrm{~g}$ sample or per $100 \mathrm{~g}$ fat, there was no significant difference between samples oxidized 0 hours and 336 days. Possibly oxidation had taken place during the handling and treatment of the meat preceeding the experimental oxidation period, so that a state of stability had been reached. This seems unlikely. It is more likely that the halogen had combined with other compounds in the meat such as porphyrin, phenylalanine and tyrosine, which contain double bonds. Hence, the iodine number does not give a true reflection of oxidative changes in meat because of possible complexing of the halogen with compounds other than unsaturated fatty acids.

With both methods of calculating the iodine number, turkey samples had significantly higher iodine numbers than beef samples. This would be expected as turkey has been shown to contain more unsaturated fat than beef (Lea, 1938). Hence, turkey would be expected to have higher iodine numbers. When calculating the iodine number as $\mathrm{g} \mathrm{I}_{2}$ absorbed per $100 \mathrm{~g}$ sample there were no significant differences between hand deboned turkey and beef samples. Other factors such as initial handling may have affected the oxidation state of the meat. Furthermore, the fact that it is suspected that the halogen is combining 
with other compounds makes this data suspect.

When the iodine number was calculated as $\mathrm{g} \mathrm{I}_{2}$ absorbed per $100 \mathrm{~g}$ fat, there was a significant difference between hand deboned turkey and mechanically deboned turkey. However, this could be in part attributed to the fact that the hand deboned turkey contained 15.9\% 1ipid and the mechanically deboned turkey contained $39.2 \% 1$ ipid. A 0.2 g sample of meat was used when testing for iodine number. Hence, the amount of lipid in the hand deboned sample was much less. The high iodine number is a reflection of the method of calculation. In addition, the fact that iodine numbers for hand deboned turkey were very similar to values for mechanically deboned turkey when calculated as $\mathrm{g} \mathrm{I}_{2}$ absorbed per $100 \mathrm{~g}$ sample gives substance to the possibility of $\mathrm{I}_{2}$ combining with other compounds.

The iodine number calculated of 257 for fat from hand deboned turkey oxidized 0 hours is very unrealistic. An iodine number of 122.6 is listed in weast (1968) for corn oil. The iodine number for corn $0 i 1$ was determined to be 117.2 for a sample in our laboratory. The iodine number for fresh chicken fat was determined in our laboratory to be 98 . This determination was completed within three hours of the slaughter of the chicken. (The chicken fat was obtained from the Utah State Poultry Farm, Logan, Utah). Although the iodine number is usually expressed as $\mathrm{g} \mathrm{I}_{2}$ absorbed per $100 \mathrm{~g}$ lipid, this appears highly inaccurate on our meat samples.

In conclusion, using both the TBA value and the iodine number as measures of oxidation on turkey and beef samples proved frustrating. The TBA value has proved unreliable in dry systems. The iodine number appears to have the fault of the halogen combining with other compounds 
when a meat sample instead of a lipid is tested. 


\section{FINAL STATEMENT}

Two studies were conducted to determine the effect of atmospheric oxidation on bioavailability of meat iron and liver weights in rats. The first experiment did not show a relationship between iron deficiency and oxidation time of turkey meat. The second experiment demonstrated that only rats fed lyophilized beef that had been oxidized at $20-22^{\circ} \mathrm{C}$ for 336 hours had impaired iron metabolism. Rats fed fresh lyophilized beef diets with added formaldehyde did not exhibit the same hematinic responses as rats fed oxidized beef.

As the results of the first two experiments varied, a third experiment on lyophilized turkey and beef meat was conducted to try to account for the variability in results between Experiment 1 and 2 . Although every attempt was made to duplicate the meats used in Experiment 1 and 2, the percentage meat composition of protein, lipid and iron varied greatly in the hand deboned turkey and mechanically deboned beef. Furthermore, attempts to reproduce formaldehyde values TBA values, and iodine numbers met with obstacles. Further testing will be necessary to develop reliable techniques for testing oxidation in lyophilized meats.

The turkey and beef meats which had been allowed to oxidize were unacceptable for human consumption because of the extremely rancid odor. As the degree of oxidation in 1yophilized meat must be very high before a significant depression of growth and hematinic response occurs in laboratory animals, it is not likely that humans would eat enough severely oxidized meat to affect the bioavailability of iron in the diet. 


\section{REFERENCES}

AMA (American Medical Association, Committee on Iron Deficiency). 1968. Iron deficiency in the United States. J. Am. Med. Assoc. 203:407.

Al1red, L. 1976. Some effects of mechanical deboning on the composition and the bioavailability of protein and iron in turkey frame meat. MS thesis, Utah State University.

Amano, K. and K. Yamada. 1964. A biological formation of formaldehyde in the muscle tissue of gadoid fish. Bul1. Japanese Soc. Scientific Fisheries 30:430.

Amine, E. K. and D. M. Hegsted. 1975. Effect of dietary carbohydrates and fats on inorganic iron absorption. J. Agr. Food Chem. $23: 204$.

Andia, A. M. G. and J. C. Street. 1975. Dietary induction of hepatic microsomal enzymes by thermally oxidized fats. Ag. Food Chem. $23: 173$.

Andrews, J. S., J. F. Mead and W. H. Griffeth. 1956. Toxicity of lipid peroxides in the rat. Fed. Proc. 15:918.

Andrews, S. J., C. G. Ponce and V. T. Mendenha11. 1977. Recovery of formaldehyde from mechanically deboned turkey. J. Food Sci. $42: 1168$.

Bjorn-Rasmussen, E. 1974. Iron absorption from wheat bread -influence of various amounts of bran. Nutr. Metabol. 16:101.

Bjorn-Rasmussen, E. and L. Hal1berg. 1974. Iron absorption from maize. Nutr. Metabol. 16:94.

Carmer, S. G. and M. R. Swanson. 1973. An evaluation of 10 pairwise multiple comparison procedures by Monte Carlo methods. J. Am. Stat. Assoc. 68:66-74.

Cook, J. D. and E. R. Monson. 1976. Food iron absorption in human subjects. III. Comparison of the effects of animal protein on nonheme iron absorption. Am. J. Clin. Nutr. 29:859.

Cook, J. D. and E. R. Monson. 1977. Vitamin C, the common cold, and iron absorption in man. Am. J. Clin. Nutr. 30:235.

Crosby, W. H., S. I. Munn and F. W. Furth. 1954. Standardized method for clinical hemoglobinometry. U.S. Armed Forces Med. J. $5: 693$.

Danie1, L. J. and A. L. Nea1. 1967. Laboratory experiments in biochemistry. New York: Academic Press. 
Farmer, B. R. A. 1977. The iron bioavailability of mechanicallydeboned meats. M.S. thesis, Utah State University.

Farmer, B. R., A. W. Mahoney, D. G. Hendricks and R. A. Gillett. 1977. Iron bioavailability of hand-deboned and mechanically deboned beef. J. Food Sci. 42:1630.

Fennema, 0. R. 1976. Principles of Food Science. Part 1. Food Chemistry. New York: Marcel Dekker, Inc.

Gray, J. I. 1978. Measurement of lipid oxidation: a review. J.A.O.C.S. $55: 539$.

Greenberg, S. M. and A. C. Frazer. 1953. Some factors affecting the growth and development of rats fed rancid fat. J. Nutr. 50:421.

Haurowitz, F. 1963. The chemistry and function of protein, 2nd ed., New York: Academic Press.

Hegsted, D. M., C. A. Finch and T. D. Kinney. 1949. The influence of diet on iron absorption. II. The interrelation of iron and phosphorus. J. Exp. Med. 90:147.

Hutchins, B. K., T. H. P. Liu and B. M. Watts. 1967. Effects of additives and refrigeration on reducing activity, metmyoglobin and malonaldehyde of raw ground beef. J. Food Sci. 32:214.

Kaufman, N., J. V. Klavis, and T. D. Kinney. 1958. Excessive iron absorption in rats fed low-protein, high-fat diets. Lab. Invest. 7:369.

Kaunitz, H., R. E. Johnson and L. Pegues. 1965. A 1ong-term nutritional study with fresh and mildiy oxidized vegetable and animal fats. J.A.O.C.S. $42: 770$.

Kaunitz, H., R. E. Johnson and L. Pegues. 1966. Longer survival time of rats fed oxidized vegetable oil. Proc. Soc. Exp. Biol. Med. 123:204.

Kaunitz, H., C. A. Slanetz and R. E. Johnson. 1955. Antagonism of fresh fat to the toxicity of heated and aerated cottonseed $0 i 1$. J. Nutr. $55: 577$.

Kaunitz, H., C. A. Slanetz, R. E. Johnson, H. B. Knight, D. H. Saunders and D. Swern. 1956. Biological effects of the polymeric residues isolated from autoxidized fats. J.A.0.C.S. 33:630.

Labuza, T. P. 1980. The effect of water activity on reaction kinetics of food deterioration. Food Technol. 34, No. 4:36.

Layrisse, M., C. Martinez-Torres and M. Roche. 1968. Effect of interaction of various foods on iron absorption. Am. J. Clin. Nutr. $21: 1175$. 
Lea, C. H. 1938. Rancidity in edible fats. Food Investigation Special Report No. 46. Great Britain Dep. Sci. and Ind. Res.

Mahoney, A. W. and D. G. Hendricks. 1976. Effects of dietary iron level on efficiency of converting food iron into hemoglobin by the anemic rat. Nutr. Metab. 20:222.

Mahoney, A. W., C. C. Van Orden and D. G. Hendricks. 1974. Efficiency of converting food iron into hemoglobin by the anemic rat. Nutr. Metab. 17:223.

Mendenha11, V. T. 1970. The isolation and identification of a microbial indhibitor for Pacific hake (Merluccius productus). Ph.D. dissertation, Oregon State University, Corvallis.

Miller, J. and D. R. Landes. 1975. Effects of feeding oxidized or heated soybean oil on tissue composition and hematological status of rats. J. Food Sci. 40:545.

Nakamura, M., H. Tanaka, Y. Hattori and M. Watanabe. 1973. Biolgoical effects of autoxidized safflower oils. Lipids 8:566.

National Research Council. 1980. Recommended Dietary Allowances, 9th ed. Washington, D.C.: National Academy of Sciences.

Nolen, G. A. 1973. A feeding study of a used, partially hydrogenated soybean oil, frying fat in dogs. J. Nutr. 103:1248.

Nolen, G. A., J. C. Alexander and N. R. Artman. 1967. Long-term rat feeding study with used frying fats. J. Nutr. 93:337.

Pike, R. L. and M. L. Brown. 1975. Nutrition: An Integrated Approach, 2nd ed. New York: John Wiley \& Sons, Inc.

Shamberger, R. J., B. A. Shamberger and C. E. Willis. 1977. Malonaldehyde content of food. J. Nutr. 107:1404.

Sinnhuber, R. 0. and T. C. Yu. 1958. 2-Thiobarbituric acid method for the measurement of rancidity in fishery products. II. The quantitative determination of malonaldehyde. Food Technol. 12:9.

Stout, F. M., J. E. 01dfield and J. Adair. 1960a. Aberrant iron metabolism and the "cotton-fur" abnormality in mink. J. Nutr. $72: 46$.

Stout, F. M., J. E. O1dfield and J. Adair. 1960b. Nature and cause of the "cotton-fur" abnormality in mink. J. Nutr. 70:421. 
Tarladgis, B. G., B. M. Watts, M. T. Younathan and L. Dugan, Jr. 1960. A distillation method for the quantitative determination of malonaldehyde in rancid foods. J.A.0.C.S. 37:44.

Van Campen, D. 1974. Regulation of iron absorption. Fed. Proc. $33: 100$.

Waddel1, J. 1974. The bioavailability of iron sources and their utilization in food enrichment. Fed. Proc. 33:1779.

Weast, R. C. ed. 1968. Handbook of Chemistry and Physics, 49th ed. Cleveland: The Chemical Rubber Co. 
APPENDICES 
APPENDIX A

\section{Micro Kjeldahl Method}

Weigh by difference a finely ground, homogenous, dried food sample. Use 0.1000 to $0.1500 \mathrm{~g}$ of meat. Weigh the sample on to a sam11 piece of waxed paper and transfer to the Kjeldahl flask. Weigh the paper.

Run two reagent blanks through all the steps of the procedure and subtract the blank titration from the sample titrations.

Add approximately $1 \mathrm{~g}$ of the catalyst mixture $\left(9: 1 \mathrm{Na}_{2} \mathrm{SO}_{4}: \mathrm{CuSO}_{4}\right)$ with a small measuring scoop followed by $4 \mathrm{ml}$ concentrated $\mathrm{H}_{2} \mathrm{SO}_{4}$. Wash down neck with small amount of distilled water. Add henegar granule to flask.

Place the flask on the digestion apparatus under a hood with the exhaust fan on. Cook until the solution is a clear aqua (approximately 5 hours). Swirl sample occassionally.

Allow the flasks to cool. Wash the neck of the flask down with a wash bottle to dilute the sample to about $10 \mathrm{ml}$. Transfer the clear solution to a distillation flask with a series of 3-4 small rinses with distilled water. Place the flask in an ice bath to cool before distilling.

The steam distillation apparatus should be heating while preparing samples. When boiling vigorously, turn on cold water in the condensor. Place $10 \mathrm{ml}$ of the boric acid solution (4\% boric acid $+5 \mathrm{ml} 0.4 \%$ bromocresol green in ethyl alcohol) in a $50 \mathrm{ml}$ Erlenmeyer flask and set it under the condenser with the tip below the surface of the solution. The distillation flask should be clamped into position. 
Add $20 \mathrm{ml} \mathrm{NaOH}$ (45\% solution) and quickly turn on the steam. Let the distillation proceed for 5 minutes after the product appears, or until 10-15 $\mathrm{ml}$ of distillate have been collected. Let the flask down below the condensor and let it drip for an additional minute. Turn off the steam, remove the distillation flask, and rinse the tip of the condensor into the collection flask.

Titrate the sample with standardized $0.05 \mathrm{~N} \mathrm{HCl}$ to a faint green end point.

Calculation

$\%$ Nitrogen $=(m 1$ acid $-m 1$ blank) (acid normality) $\times 0.014 \times 100$ titrated titrated

wt. of sample in $\mathrm{g}$

$\%$ crude protein $=\%$ nitrogen $\times 6.25$ 
APPENDIX B

Soxhlet Method

Weigh filter paper. Weigh $1.0-1.5 \mathrm{~g}$ sample on to filter paper. Wrap sample in filter paper, close securely, label, and record total weight.

Dry overnight in vacuum oven at $60^{\circ} \mathrm{C}$.

Cool in dessicator. Weigh. Determine percentage moisture.

Extract lipid from sample in Soxhlet apparatus using petroleum ether as the solvent for approximately 10-12 hours.

Dry packaged sample in $60^{\circ} \mathrm{C}$ oven overnight. Cool in dessicator. Record weight. Determine percentage lipid. 
APPENDIX C

\section{2-Thiobarbituric Acid Method (TBA)}

Weigh a $250 \mathrm{ml}$ boiling flask and record weight. Add a $1 \mathrm{~g}$ sample of meat. Record weight.

Add $5 \mathrm{ml}$ water, $6 \mathrm{ml}$ TBA, $5 \mathrm{ml}$ pyridine $\mathrm{HCl}$ solution (300 ml pyridine and $700 \mathrm{ml} 6 \mathrm{~N} \mathrm{HCl}$ ), and $10 \mathrm{ml}$ of TCA solution (20\% Trichloroacetic Acid). Connect to condensor and cook for 30 minutes exactly.

Add $70 \mathrm{ml}$ of $0.6 \mathrm{~N} \mathrm{HCl}$. Swirl gently. Heat another 10 minutes. Cool for 10 minutes or to room temperature.

Pour $30 \mathrm{ml}$ of sample into $50 \mathrm{ml}$ centrifuge tube and centrifuge for 10 minutes at $17.65 \mathrm{G}$. Pipet $10 \mathrm{ml}$ of petroleum ether into a centrifuge tube. Pipet $15 \mathrm{ml}$ of sample into tube containing petroleum ether. Shake by hand for 1 minute. Centrifuge for 5 minutes at $17.65 \mathrm{G}$.

Read OD immediatley in Beckman DB Spectrophotometer at $535 \mathrm{mu}$ against a water blank.

Place $0,1,2,4,6,10,15,20 \mathrm{ml} 1 \mathrm{ppm}$ malonaldehyde standard solution in $250 \mathrm{ml}$ boiling flask. Follow steps above. Calculate regression line for malonaldehyde. Calculate $\mu \mathrm{g}$ malonaldehyde per gram sample. 
APPENDIX D

Iodine Number

Rinse glass stoppered $250 \mathrm{ml}$ Erlenmeyer flasks with dry chloroform. Weigh flasks when theyare completely dry. Add sample to flask. Weigh it again.

Add $10 \mathrm{ml}$ anhydrous chloroform to each flask.

From an automatic buret under the hood, add exactly $25 \mathrm{ml}$ of pyridine sulfate dibromide to each flask. (Space flasks about 15 minutes apart). Stopper flasks and place them in the dark (in a drawer) for exactly 30 minutes.

Add $10 \mathrm{ml}$ of $15 \%$ potassium iodide to the flasks. Mix the contents well by shaking the flasks.

Add $75 \mathrm{ml}$ of $\mathrm{H}_{2} \mathrm{O}$ to each fiask.

Titrate the $\mathrm{I}_{2}$ with approximately $0.1 \mathrm{~N}$ standardized sodium thiosulfate. Titrate to a light yellow color, then add $5 \mathrm{ml} 7 \%$ starch indicator solution and complete the titration while shaking. Note the volume on the buret just after one drop has changed the solution from blue to colorless.

Preparation of pyridine sulfate dibromide. Prepare this in an ice bath in the hood:

a. 8 g pure pyridine in $20 \mathrm{ml}$ glacial acetic acid.

b. $10 \mathrm{~g}$ conc. $\mathrm{H}_{2} \mathrm{SO}$ in $20 \mathrm{ml}$ glacial acetic acid.

Combine $a$ and b. Then add $8 \mathrm{~g} \mathrm{Br}_{2}$ in $20 \mathrm{ml}$ glacial acetic acid. Make to 1 liter with glacial acetic acid. The resulting solution is $0.1 \mathrm{~N}$. 